Journal of Urban Design, Vol. 5, No. 3, 237-265, 2000

\title{
Hexagonal Planning in Theory and Practice
}

\author{
ERAN BEN-JOSEPH \& DAVID GORDON
}

ABSTRACT Residential neighbourhood designs with street patterns based upon hexagonal blocks were proposed by several planners in the early 20th century. Urban designers such as Charles Lamb, Noulan Cauchon and Barry Parker demonstrated the economic advantages and efficient land use generated by hexagonal plans. By 1930, hexagonal planning was a leading theoretical alternative to the rectangular grid for residential subdivisions, but it was displaced by the loop and cul-de-sac model developed in Radburn, New Jersey, by Clarence Stein and Henry Wright. The paper chronologically reviews the various hexagonal planning schemes and their designers. It considers the advantages and disadvantages of hexagons, using their designers' own words and drawings.

\section{Introduction}

In the realm of urban design, hexagonal planning is today virtually an unknown phenomenon, a mere oddity among a vast array of ideologies, theories and methods. It regularly goes unnoticed by students of city planning and urban history. Yet, for a period of almost 30 years, between 1904 and 1934, it caught the attention of various planners, engineers and architects who saw in it a promising panacea for the city's planning ills and a replacement for the uniform rectangular street grid. Striving to establish visionary and idealistic schemes for a perfect physical environment that would also improve social conditions, these individuals advocated their ideas in papers and professional presentations for over a quarter of a century. Yet none were able to build their plans on a large scale. Why was this so? Was it because in reality, as on paper, hexagons looked too far-fetched to be a workable solution? What about the theory's suggested cost-effectiveness and efficient land use pattern; were not they an incentive for construction?

Such idealized geometrical schemes for city design often remained theoretical. There have been many more ideal cities on paper than on the ground. When they were built, these ideal communities were often short-lived in their pure state. They were overtaken by the reality of the way in which people behave under normal conditions. As Lynch (1984, p. 48) suggested, "Settlement form is the spatial arrangement of persons doing things, the resulting spatial flows of persons, goods, and information, and the physical features which modify space in some way significant to those actions, including enclosures, surfaces, channels, ambience, and objects".

Eran Ben-Joseph, Department of Urban Studies and Planning, Massachusetts Institute of Technology, 77 Massachusetts Ave, Cambridge, MA 02139,USA. Email: ebj@mit.edu.

David Gordon, School of Urban and Regional Planning, Queen's University, Ontario, Canada. 
Geometric plans emerged through a rational process unrelated to ideal-city concepts. While we might view hexagonal planning as one of those fanciful approaches to city design, we should not dismiss it entirely. The conceptual framework that delineates hexagonal planning and design is outlined in this paper through a review of professional publications, historical precedents and archival research. The article mainly addresses hexagonal planning at the neighbourhood and metropolitan scale, and largely ignores other interesting hexagonal schemes in architecture (Bijlmermeer, Amsterdam; Le Mirail, Toulouse) or traffic engineering (Buchanan, 1963). Hexagonal planning's key advocates and its historical context are describe chronologically below.

Geometric approaches to the planning of towns and villages have many precedents in the form of ancient cities (Castagnoli, 1971). The rectangular grid was by far the most prevalent design, with examples in China, India, Rome and Greece (Kostof, 1991). Octagonal layouts were also popular for ideal cities such as Palmanova, Italy (1593), and Hamina, Finland (1723) (Johnston, 1983). Wren's proposal for rebuilding London after the Great Fire (1666) combined grids with octagonal and hexagonal geometry, but it was not built (Figure 1). A small portion of Woodward's 1807 hexagonal/rectangular grid plan for Detroit was built before the town abandoned the idea in the 1820s (Figure 2). The Edinburgh New Town (1795) and Goderich, Ontario (1829), successfully incorporated a rectangular grid and octagonal squares. These elegant diagrams were often the exceptions to the rule of the rectangular grid. The gridiron plan was mandated by ordinances in the Spanish Laws of the Indies, the French Bastille towns, the UK bylaw housing estates and the 19th-century North American land surveys. In North America, most towns from Edmonton to Mexico City were laid out in some form of rectangular grid (Reps, 1969). When the modern urban planning movement began around the turn of the 20th century, this grid was an obvious target for reform, since it was regarded as monotonous, excessively paved and open to through traffic (Southworth \& Ben-Joseph, 1997).

\section{Garden Cities and Garden Suburbs as Alternatives for Residential Neighbour- hoods (1899-1930)}

Ebenezer Howard's influential book Tomorrow: A Peaceful Path to Real Reform (1898) contained now-famous diagrams proposing garden cities in a circular form. Even Howard regarded these drawings as theoretical illustrations of his concept. The designers of Letchworth (1903), the first garden city, were given a free hand. The winning design in the limited competition for Letchworth was prepared by Raymond Unwin and Barry Parker, two architects deeply involved in social reform. Miller (1989) suggests that the semi-octagonal design of the proposed town centre (Figure 3) seems inspired by Wren's proposal for the business district of London. However, Unwin and Parker's small house groupings became far more influential. They experimented with small crescents and cul-de-sacs for inexpensive cottages in Letchworth's residential areas.

Unwin and Parker's design for Hampstead Garden Suburb (1907-1910) extended this theme of informally planned residential areas with detailed site planning for middle-class homes, based upon small crescents and cul-de-sacs. Frederick Law Olmsted, Jr, took a similar approach for an early US garden suburb in Forest Hills Garden, New York (1911). He combined small groups with the graceful curvilinear designs pioneered by his father in 1869 at River- 


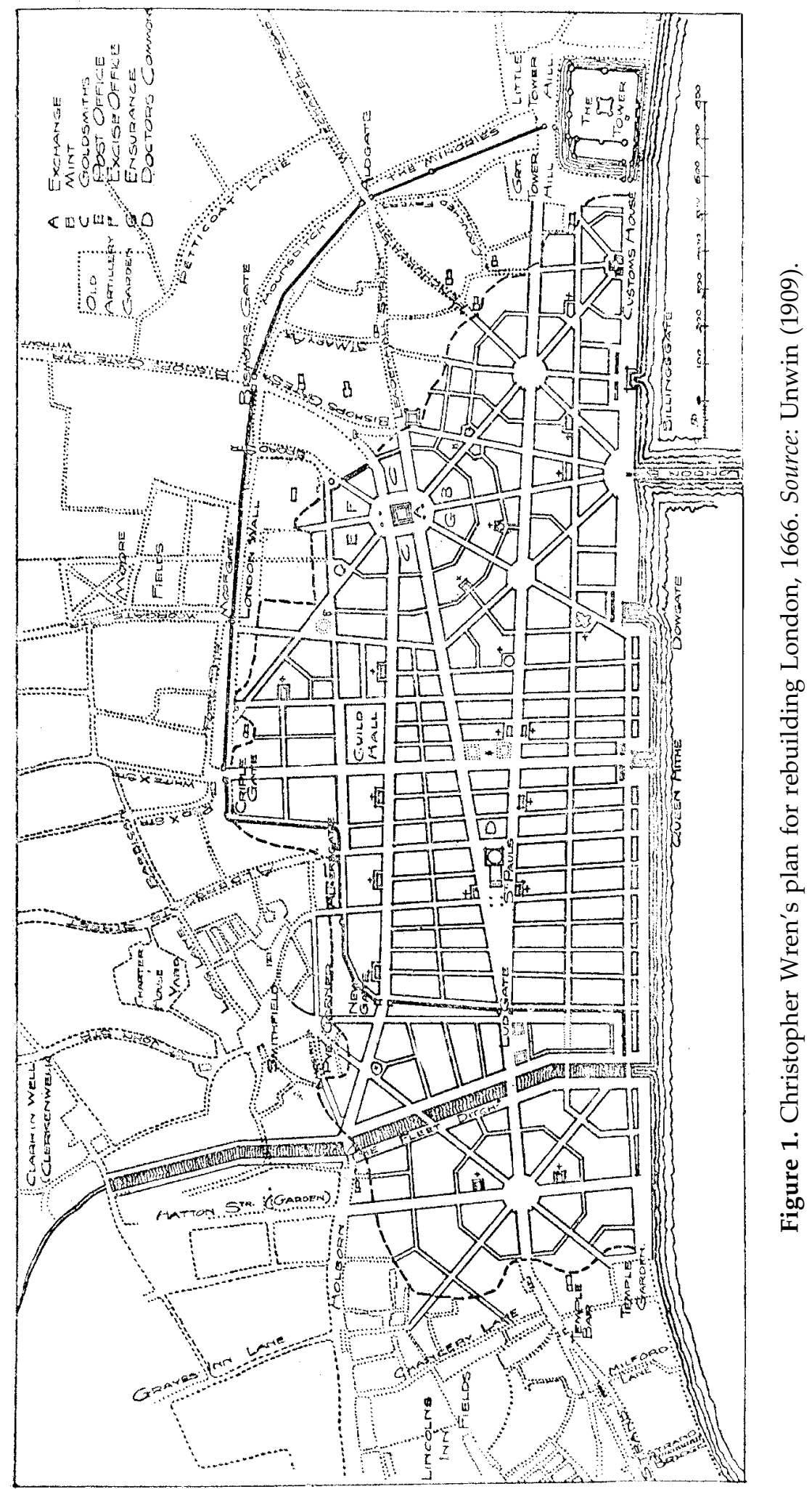




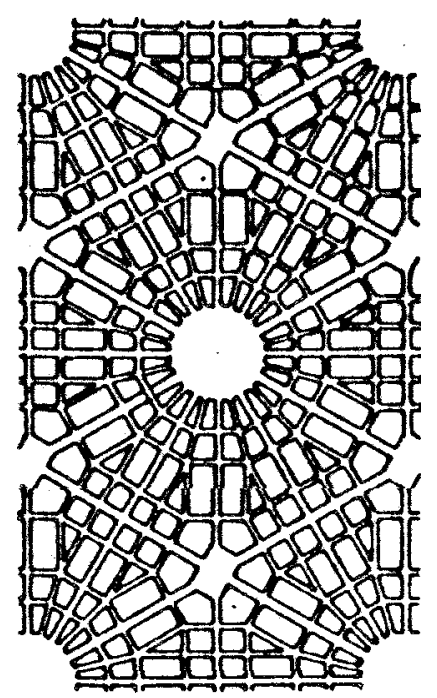

Figure 2. Woodward's hexagonal/rectangular grid plan for Detroit, 1807. Source: Cauchon (1927).

side, near Chicago. The Olmsted Bros. firm produced scores of curvilinear subdivisions in the USA and Canada in the early 20th century.

\section{The City Beautiful and the Grid (1904-1920)}

One of the principal disadvantages of the rectangular grid is the difficulty of diagonal movements, which make up a large proportion of urban trips. Urban designers often attempted to combine diagonal boulevards with a background grid, following the example of L'Enfant's plan for Washington, DC (1793), or Cerdás plan for the Barcelona Ensanche (1864). The diagonal Parisian boulevards created by Baron Haussmann in the late 19th century were particularly influential, perhaps because the Ecole des Beaux Arts was the dominant architectural school of the day. The classical architectural and urban design ideals of the Ecole were reintroduced to North America in the World's Columbian Exposition at Chicago in 1893. The fair's plan, coordinated by Daniel Burnham, had a strong influence upon urban design practice for the next 20 years. Its vision of immense, white neo-classical buildings facing naturalistic landscapes and lagoons created a powerful image which was widely reproduced in early photographic souvenirs.

Attempts to recreate the fair's image became known as the City Beautiful movement (Wilson, 1989). Burnham and Edward Bennett's plans for San Francisco (1904) and Chicago (1909) combined the existing city grids with neo-classical civic centres at the focus of the new diagonal avenues. Washington, DC, revived L'Enfant's plan in 1903, and Philadelphia inserted a major diagonal avenue, the Fairmount Parkway, into Penn's 1692 grid plan. However, few other cities were able to follow Haussmann's lead in cutting new diagonal boulevards though an existing urban fabric. They often lacked the financial resources and expropriation powers required to match Paris's programme. By 1910, the City Beautiful was under attack for its impracticality and overly aesthetic approach 


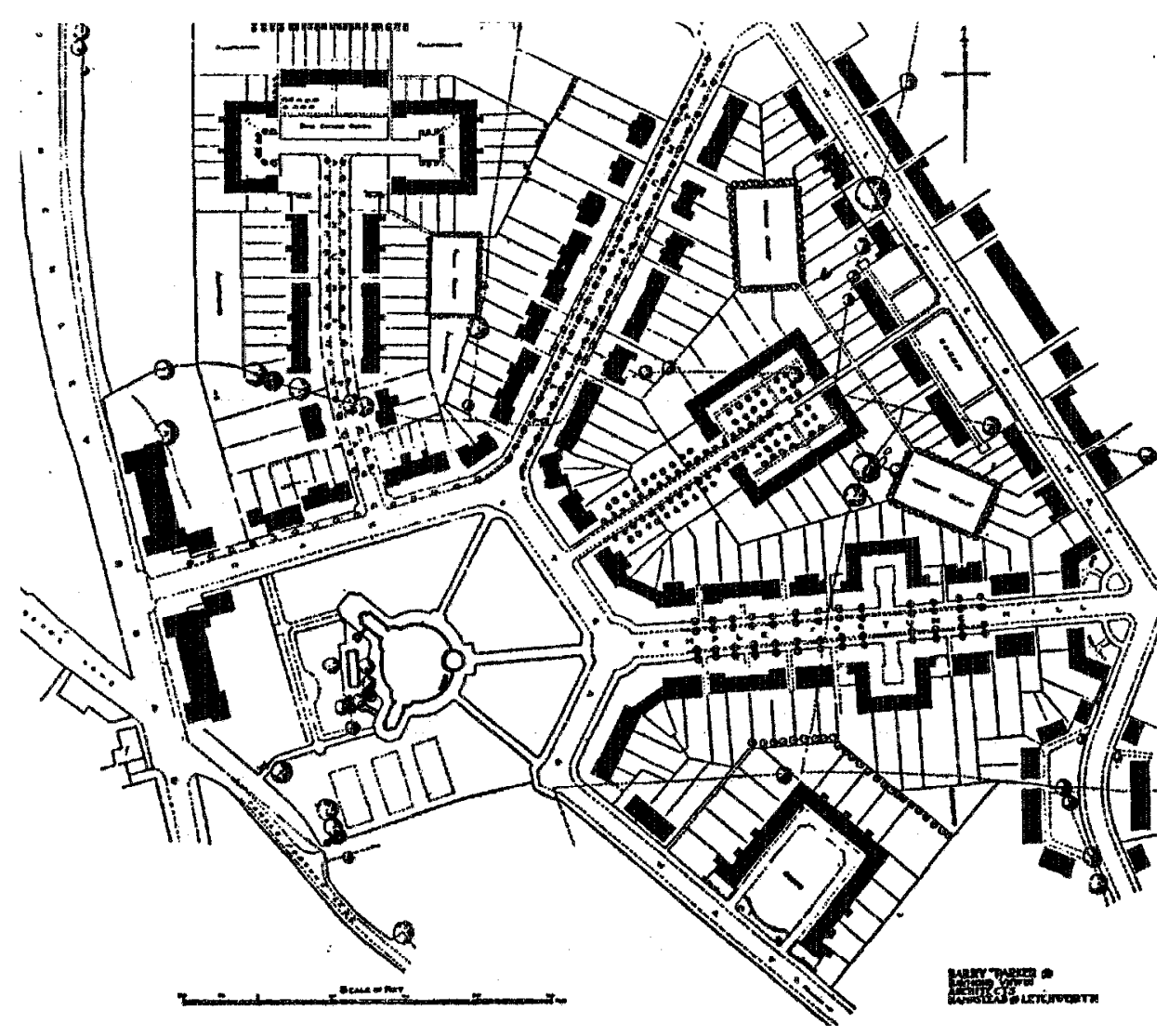

Figure 3. Hampstead Garden Suburb's courts and cul-de-sacs, Unwin and Parker, 1905. Source: Unwin (1909).

to planning (Olmsted, 1911), although diagonal boulevards were important elements of plans for national capitals on vacant sites, like Griffin's Canberra (1912) (Figure 4), and Lutyens and Baker's New Delhi (1913) (Figure 5).

In a Grand yet Prudent Manner: Charles Lamb and Rudolf Müller, Hexagonal Plans (1904-1910)

City planning and design became a subject of interest in many circles of engineers, sociologists, artists and craftsmen. Hexagonal plans were advocated by a New York architect and a Viennese engineer during the first decade of the 20th century. The New York architect and art historian Charles Lamb prepared a hexagonal plan in 1904. Lamb specialized in ecclesiastical and memorial architecture, designing the Madison Square Arch as well as the court of honour of the Hudson-Fulton Celebration in 1909. Lamb believed that arts and crafts were an integral part of architecture and city planning. He frequently addressed the need to beautify New York City through sculptures, fountains and statues as well as through the planning and design of streets and city blocks (Gilmartin, 1995). 

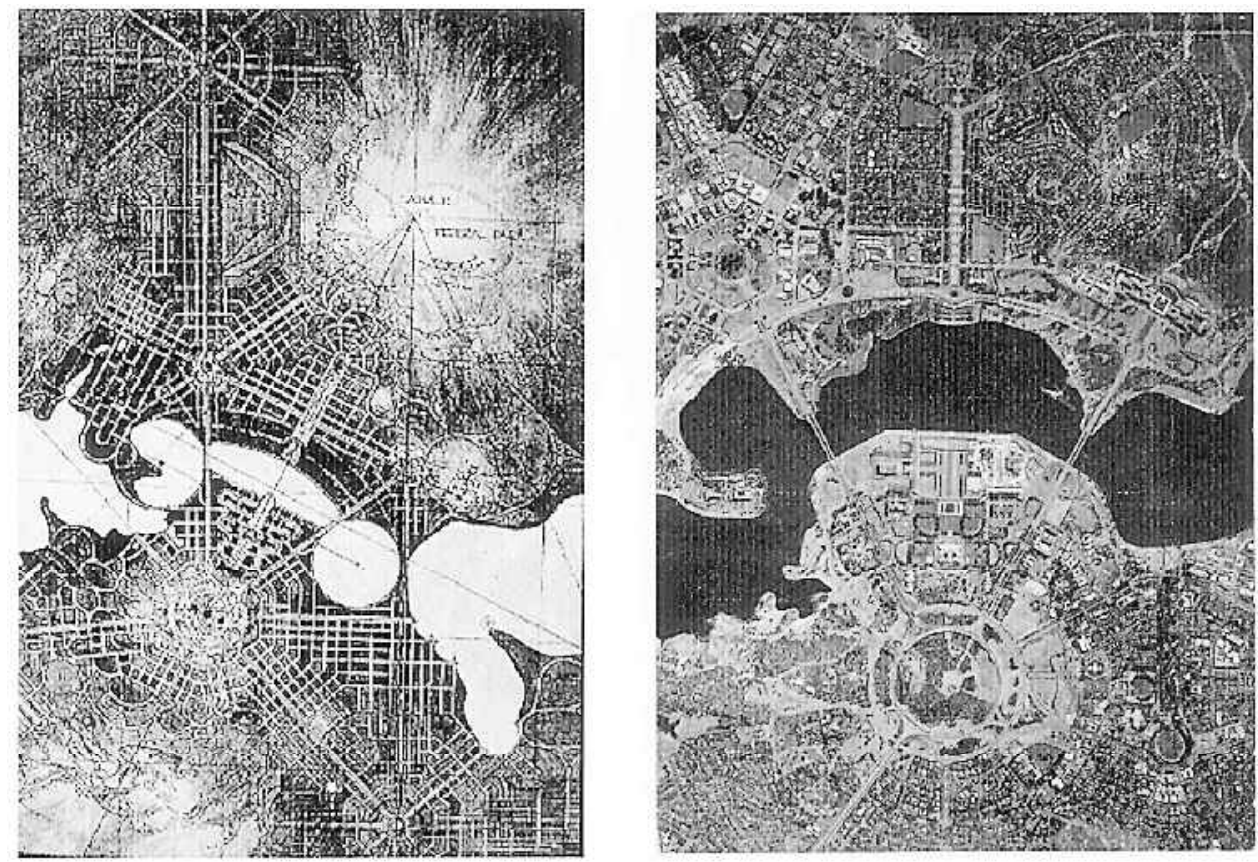

Figure 4. Canberra, Walter Burley Griffin, 1912. Source: Courtesy of City of Canberra.

In 1904, Lamb used his influential standing in the fine art circles of New York City to introduce city planning into the realm of arts and crafts. He published an article with the title 'City plan' in the Craftsman (Lamb, 1904). Lamb argued, from both artistic and economic perspectives, for the utilization of hexagonal planning for future cities and neighbourhoods.

The source of inspiration for the hexagonal configuration of city streets and blocks that Lamb advocated is unknown. He was a great admirer of L'Enfant's diagonal streets in the original plan for Washington, DC. Lamb was also critical of the grid system, in particular that of Manhattan. He wrote:

In counter-distinction to the plan of Washington, the gridiron system of New York, also the outcome of a commission, can be shown as possibly the most unsatisfactory of all forms of street arrangement, if the convenience of the citizen be considered, while the artistic possibilities have been ignored by having the rectilinear plan driven through tons and tons of natural rock to the destruction of the natural contours, and to the great expense of the community at large as well as of individual house-builders. It is a geometric axiom that the distance of two sides of a right angle triangle is greater than the third, and that, therefore, any system of transit through streets of right-angled plan, north or south, east or west, must necessarily increase the distance to be travelled, as against the diagonal streets leading from one quarter of the city to another. Broadway, the one great diagonal through New York, proves how essential such diagonals are, and it is but recently that a serious attempt has been made to suggest modifications and improvements in 


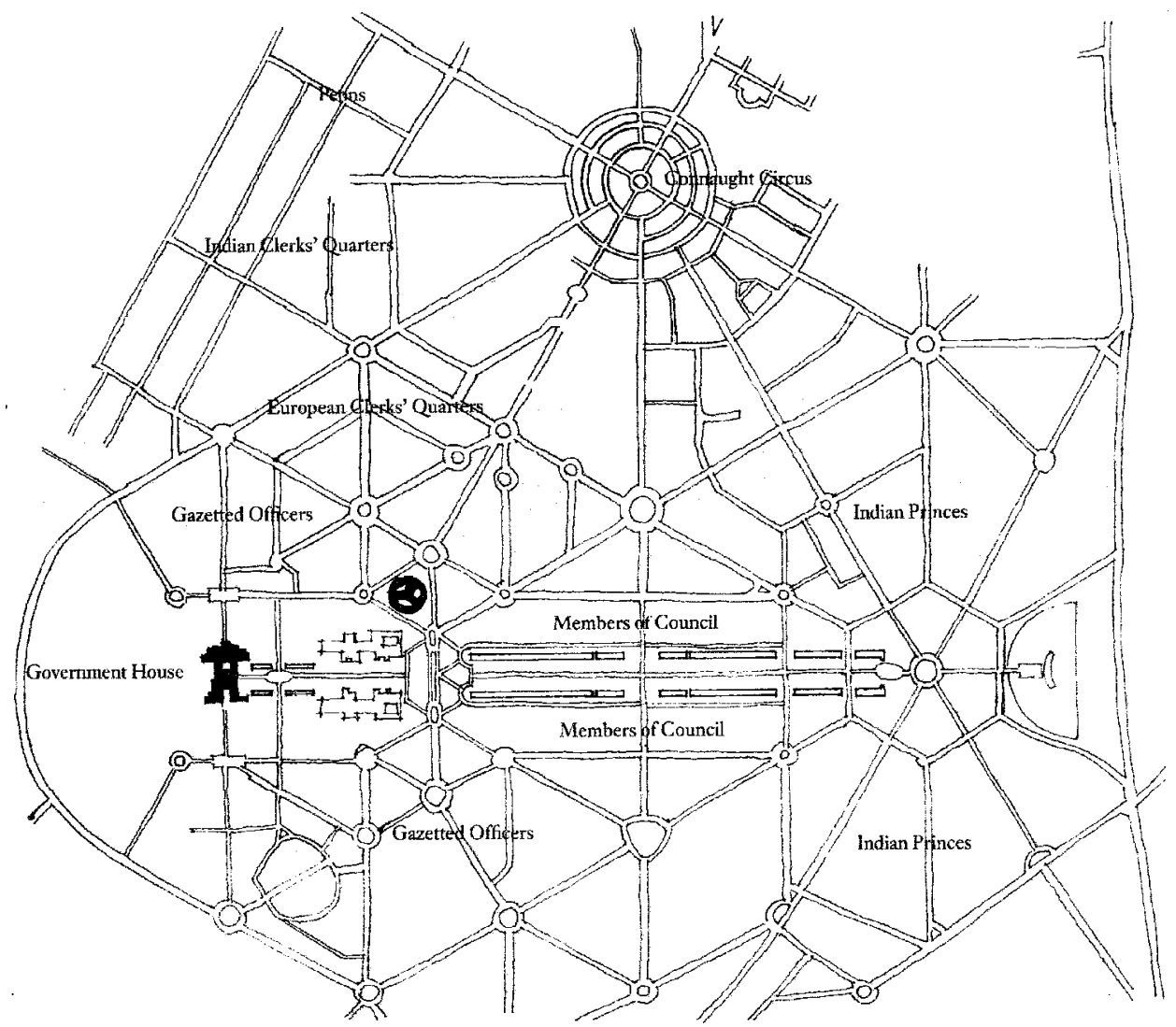

Figure 5. New Delhi, Lutyens and Baker, 1913. Source: Courtesy of Larry Vale and Saif-ul Haq.

the present plan of New York, so as to rectify many of the difficulties and adjust the changes to the inevitably increasing congestion of the growing metropolis. (Lamb, 1904, p. 5)

Lamb advocated his hexagonal city plan as a practical yet artistic solution to the ills of the modern city. He claimed that such a system would not only allow for the creation of beautiful European-style boulevards such as the Champs Elysées and Berlin's Unter den Linden, but also allow for planned growth and healthy living. "The more this plan is studied", Lamb wrote,

the more it will be found to approach the idea of practicability, primarily in regard to shorter distances that a person would have to walk or drive from any one point to another. The sub-division of the interests into groups by a division of the park area, is to be distinctly commended from its sanitary point of view, as these interruptions of natural foliage give the greatest advantage to the inhabitants of each quarter. Aesthetically, the grouping of the public, semi-public and private buildings around common centers largely increases the architectural and artistic possibilities over the accidental opportunities offered by the ordinary plan of the city; while the angles caused by the 


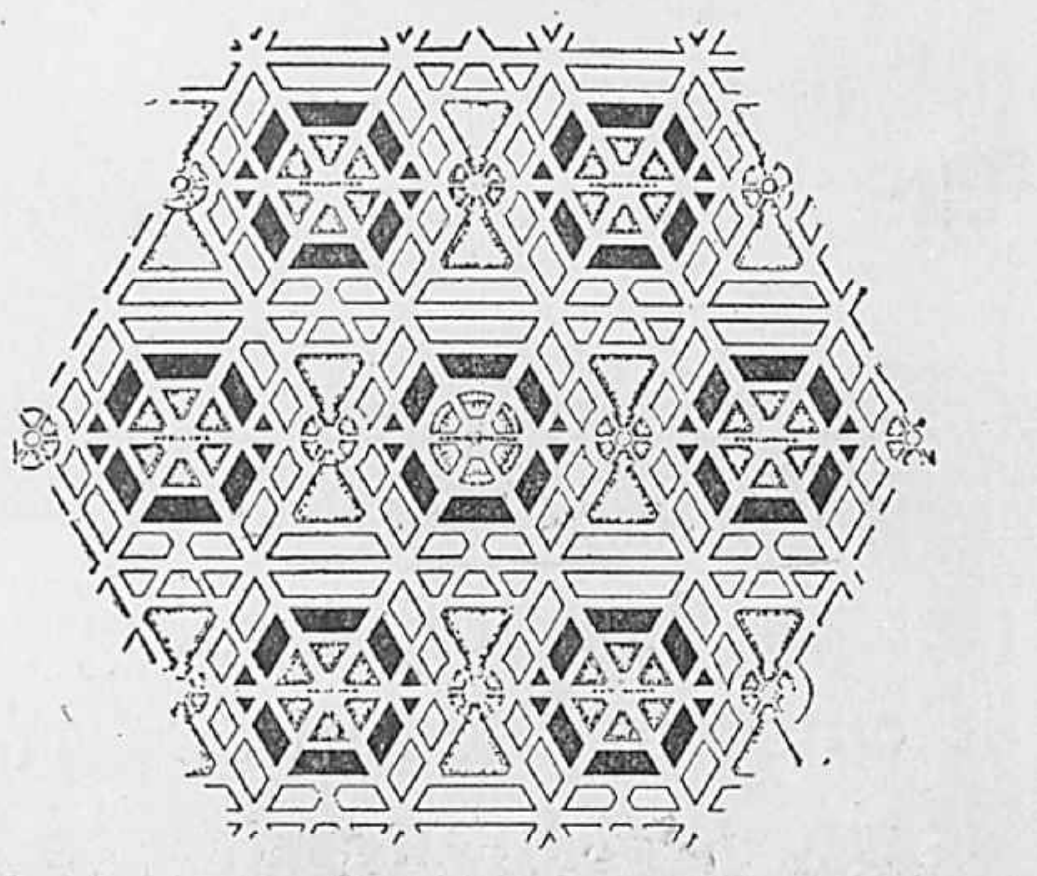

Figure 6. Hexagonal plan, Charles Lamb, 1904. Source: Triggs (1909).

hexagon permit interesting variety in the treatment of the street facades over that developed by any straight or continuously curved street. (Lamb, 1904, p. 7)

Lamb's argument for practical and aesthetic solutions to city planning in hexagonal schemes reflects the dilemma of many designers at the turn of the 20th century. The ideal of a disciplined technological city with perfect spatial order stood against the backdrop of chaotic city life, congestion and social unrest. Science and technology were seen as a vehicle for change, based on the premise that physical remedies could resolve social problems and upgrade living conditions. Salvation could come through the employment of experts and technocrats who could recommend policies and administer scientific solutions (Figure 6). Rationality inspired a fresh approach to planning, notably the adoption of the German concept of zoning and transportation systems, and the English comprehensive plan.

An Austrian engineer, Rudolf Müller, took up the challenge of devising a practical city plan. In his article 'The city of the future: hexagonal building concept for a new division', Müller (1908) claims that his inspiration arose from a pragmatic prospect of devising an efficient plan for water and sewer distribution. He writes:

So far the idea of the hexagonal building concept had pleased me, not as a city dweller, but as a system of water engineering and sewage engineering and especially still as a hygienic and nature-friendly system for public and private gardens in the city. (Müller, 1908) 
Müller drew a diagram of typical hexagonal city blocks and streets and laid out a system of utilities to prove his point. Through geometrical configurations and measurements he pointed to the potential savings in the length of the water lines as well as those for the sewer system. Fewer fire hydrants and water mains could serve a larger number of buildings, and shorter service lines could be laid between the mains and the buildings (Figure 7).

Müller also points to other aesthetic advantages:

All housing has a front width which is determined by the length of the courtyard and, of course, the street tracts running through the public courtyard, when each hexagonal building block is surrounded by six public courtyards the interior courtyards will still have reasonable dimensions relative to the housing tracts. For public monuments, fountains, and objects of beauty sufficient sizes of areas are thus given. The form of the street becomes stable by designing the street as a straight line, giving it a delightful view. With this kind of image of forms of houses and tree groupings a constructed art is created. (Müller, 1908)

Müller, like other advocates of inner city improvement in his time, drew a plan for the complete renovation of the Schmelz District in Vienna. Through his suggested plan he argues that the hexagonal concept fits well into an existing fabric and its courtyards offer better living conditions than does the typical city grid. Since Müller's schemes utilize parallel streets, creating triangles rather than full hexagonal blocks, the transition to the existing grid is more easily achieved (Figure 8).

While Müller's ideas of a hexagonal city plan have never materialized, the radial star associated with such triangular/hexagonal geometry came to be seen by many planners in the early 20th century as one of the best forms for cities. Walter Burley Griffin's design of 1912 for the Australian capital city of Canberra includes this approach. In the plan, two axes related to the topography are intersected and joined together by a series of concentric streets of hexagons and octagons. Griffin's plan, though not fully realised, had one hexagonal block that was built and two others that were reshaped into circles (Figure 4).

\section{A Regional Perspective: Arthur Comey (1923) and Walter Christaller (1933)}

The onset of World War I in 1914 and the destruction of parts of European cities sent many city reformers to the drawing table. Physical changes like those proposed by Lamb and Müller to city blocks and streets did not provide the panacea for the city's ills. As the city boundaries expanded in an unrestrained fashion, a new apparatus of planning to bridge the gap between the city, the suburbs and the open region was sought. The UK models of comprehensive planning and the garden city ideals were taking root in planning circles world-wide.

The Regional Planning Association of America (RPAA) was established in 1923 by 20 planners and architects, among them Clarence Stein, Lewis Mumford, Henry Wright, Frederick Ackerman and Clarence Perry. They developed principles for community planning to better design the metropolis and the region 


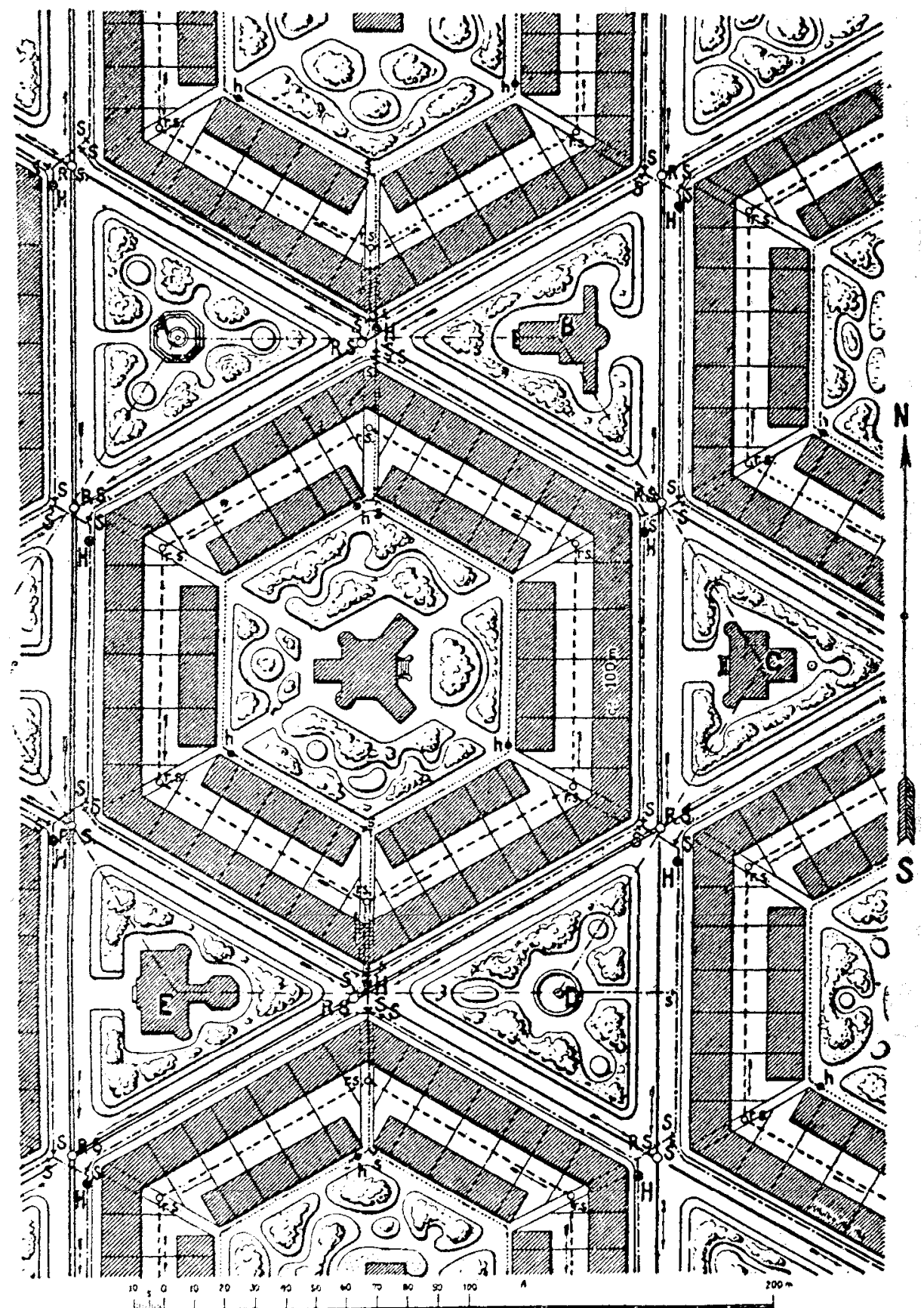

Figure 7. Hexagonal plan, Rudolph Müller, 1908. Annotations by Noulan Cauchon, 1911. "No buildings facing each other-no good for big streets. No point where more than 2 streets intersect." Source: Triggs (1909).

(Parsons, 1998). Arthur Comey was one of the great supporters of regional planning efforts at the time. A landscape architect trained by Frederick Law Olmsted, Jr, Comey was involved in many city planning efforts, including those 


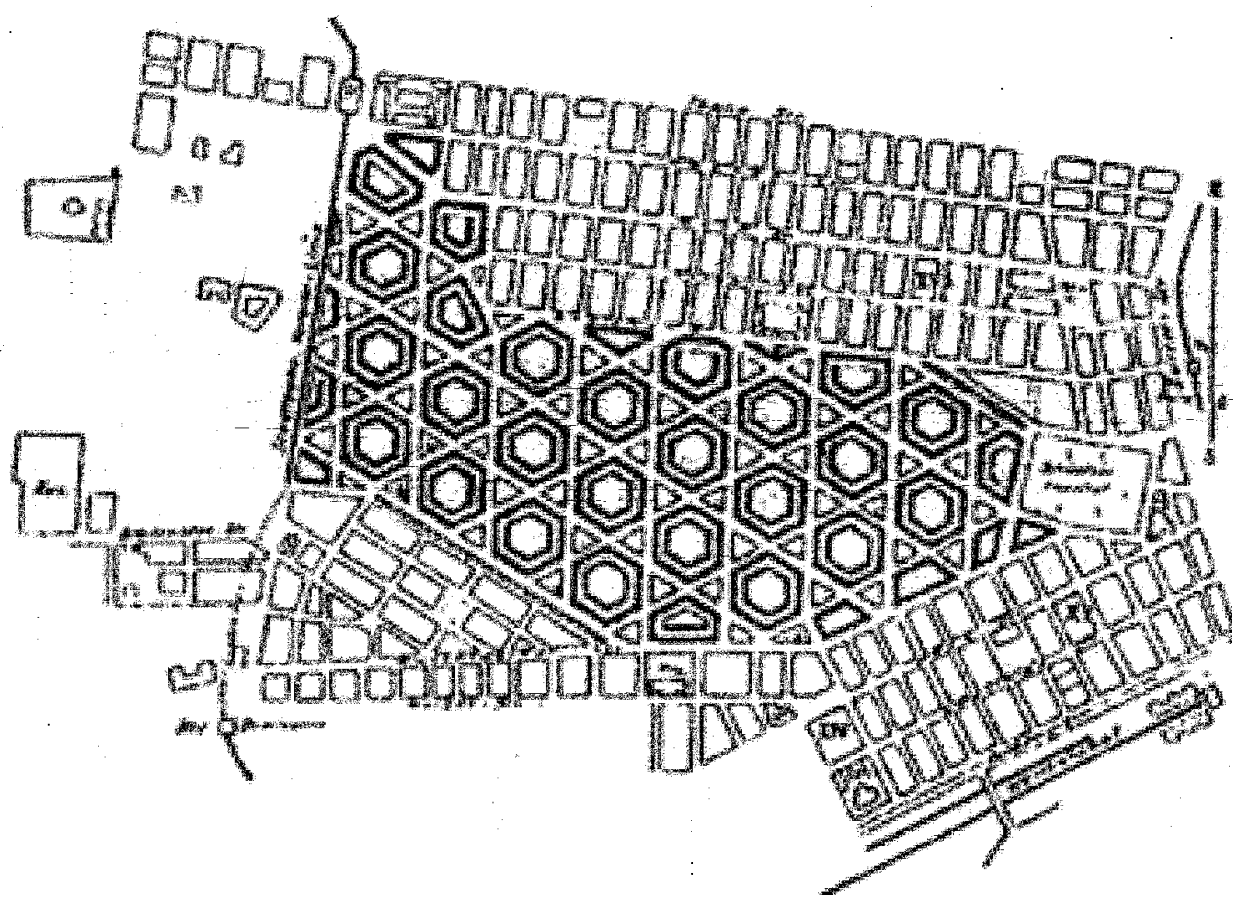

Figure 8. Schmelz District in Vienna, Rudolph Müller, 1908. Source: Müller (1908).

of Houston and Detroit. While designing numerous new neighbourhoods and districts, Comey shifted his interest to regional planning and taught the subject at the newly established Department of Regional Planning at Harvard.

In 1923 he published an intriguing scheme advocating a policy of multidirectional city growth along radial transportation lines laid out in hexagonal patterns. In Regional Planning Theory: A Reply to the British Challenge, Comey (1923) proposes that the garden city ideal as practised in England will collapse as those cities and towns grow beyond their expected population limits. Comey accurately predicted that, as population grew, congestion would increase and open space and agricultural land on the periphery would be consumed. He suggested that growth and sprawl would destroy the balance of country and city. Comey's solution was a physical plan for a city-state where networks of hexagonal and diagonal streets and prescribed land uses correspond to forces of growth. He suggested that the hexagon and the triangle used throughout his diagrams "[provide] the most serviceable and economical network of traffic routes" (Comey, 1923, p. 10). The system was progressive in scale: small towns were connected to large ones and large ones to the major metropolitan areas, creating a carpet of hexagonal cells. The nation was divided into city-regions or 'states' represented by hexagons of 1000-5000 square miles (Figure 9). Comey (1923, p. 12) wrote:

Citizens will benefit by the economics and superior results of living and working in a well-planned community; and if such a city ever does grow large the early planning should afford adequate ground work. 


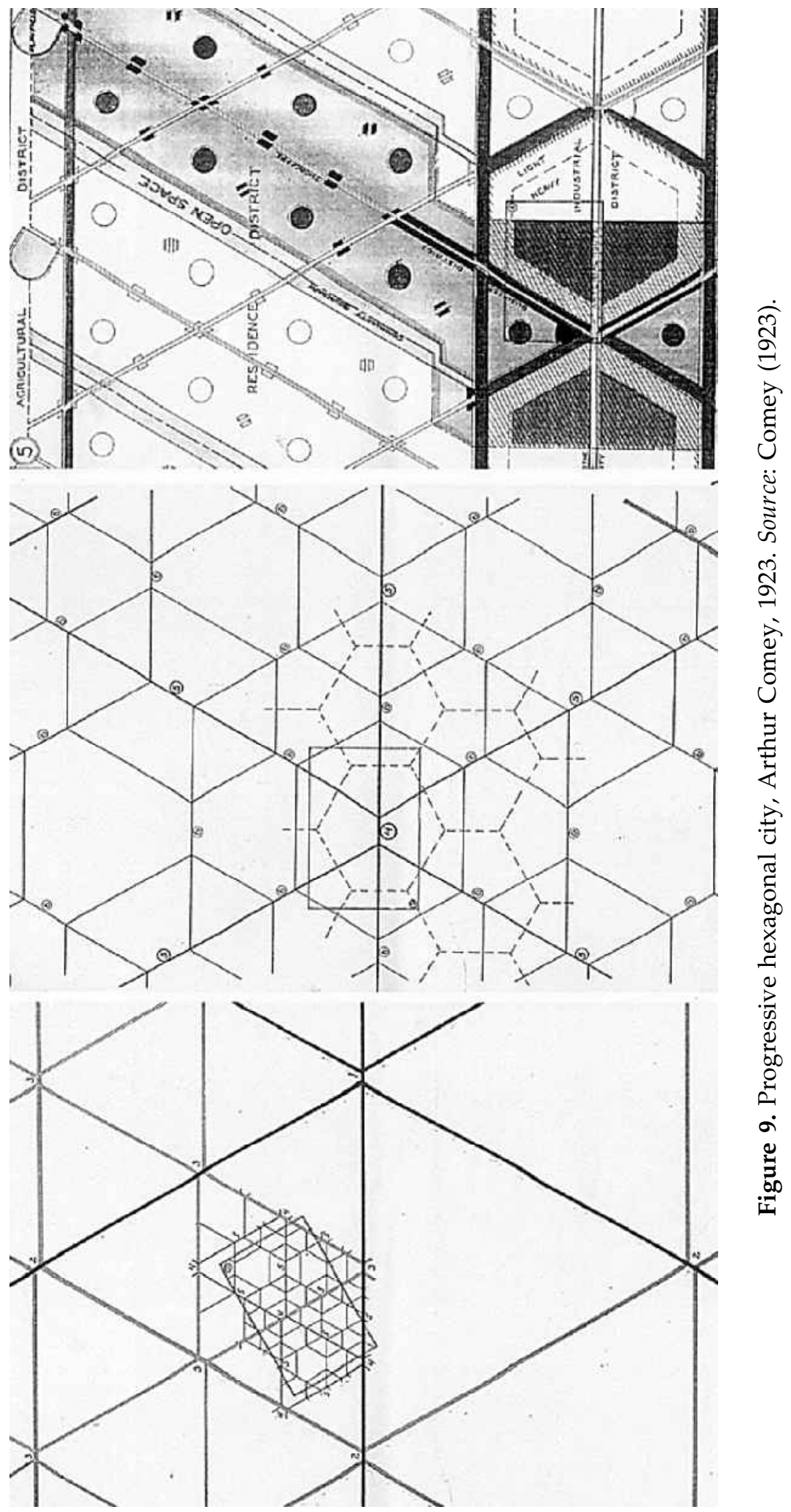


Although Comey's regional plan for a city-state remained a novelty in the US planning realm, the president of the American City Planning Institute proclaimed: "Mr Comey's suggestions are ingenious, cleverly shown by his diagrams, and basically sound" (Comey, 1923, p. 1).

Interestingly, a decade later, Walter Christaller published his Die zentralen Orte in Süddeutschland (1933) (Christaller, 1966), where he utilized almost identical diagrams to explain his popular central place theory. Whether this was a mere coincidence, or an actual cross-continental inspiration by Arthur Comey's original ideas, remains unknown. Christaller's theory became a foundation of 20th-century regional geography in Europe and North America (Yeates, 1998).

\section{The 'City Scientific' and Hexagonal Planning: Noulan Cauchon (1926-1935)}

The backlash against aesthetically based plans in the City Beautiful style was well under way by 1910, led by Thomas Adams and Frederick Law Olmsted, Jr. Adams was pivotal in making urban planning a separate profession and in codifying residential design practice. In the UK, he was the secretary of the Garden City Association and founding president of the Town Planning Institute. In 1914, he was summoned to Canada as the federal government's town planning advisor, where he prepared a few residential designs in the garden suburb style (Simpson, 1985).

Adams's main work was accomplished as an organizer and publicist for planning based on legal and scientific principles and public health. As the founding president of both the Town Planning Institute of Canada (TPIC) and the Civic Improvement League, he was instrumental in getting planning legislation adopted in most Canadian provinces (Simpson, 1985). Adams found a sympathetic colleague in Ottawa's engineer/planner, Noulan Cauchon. They made common cause against the City Beautiful plan for Ottawa prepared by Edward Bennett for the Federal Plan Commission and succeeded in getting it shelved (Gordon, 1998). Cauchon followed Adams as president of the TPIC (1921-1923) and founding chairman of the Ottawa Town Planning Commission (1921-1935), where he prepared zoning bylaws and small plans in the City Scientific manner (Coutts, 1982).

Like that of many early 20th-century planners, Cauchon's scientific approach to planning was based upon his training as a railway engineer, attendance at numerous conferences and study of the early textbooks of the day (Robinson, 1904; Triggs, 1909; Unwin, 1909). Cauchon's writings, which are preserved in Ottawa, have a strong emphasis on civic design, which he combined with his engineering experience to develop his own theory of hexagonal planning. Triggs (1909), for example, gave a detailed review of Müller's and Lamb's hexagonal plans, which Cauchon carefully annotated. Cauchon notes that Müller's plan (Figure 7) has "no buildings facing each other; no good for big streets" and approved of the land use zones in Lamb's plan. However, Cauchon's best insight may have emerged from his study of Eugene Hénard's traffic diagrams, reprinted both in Triggs (1909) and in an article he saved by Frederick Law Olmsted, Jr (1910). A three-way intersection is theoretically greatly superior to a four-way intersection because the $120^{\circ}$ angle has improved sight lines compared with the right angle. The three-legged intersection has only three potential collision points (closed circles on Figure 10), compared with 16 in the other. 


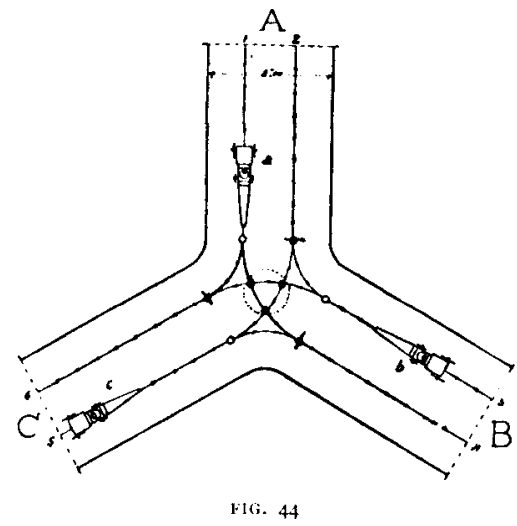

3 points of deviation from line of trafic \$ 3 points of junction with line of traffic - 3 collision points

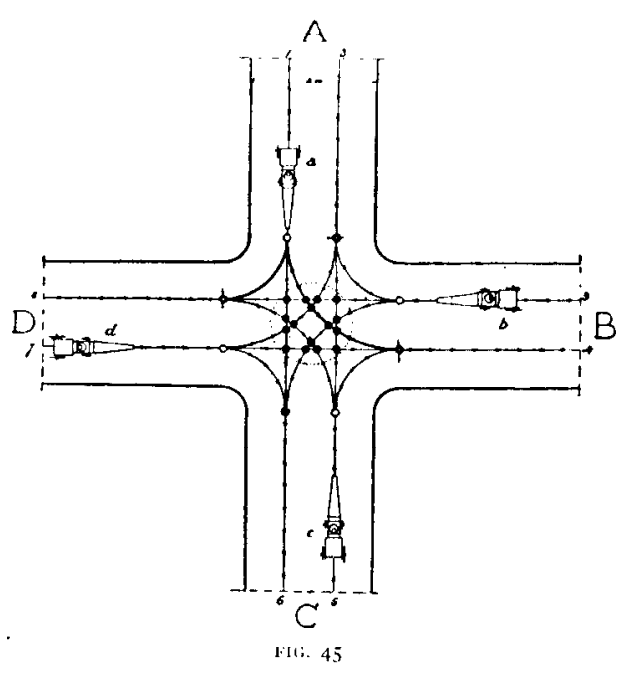

(1) 4 proints of aleviation from line of traffic 4) 4 peints of junction with line of traffic - 16 collisisn prims

Figure 10. Traffic collision points for intersection types. Source: Triggs (1909).

Cauchon (1925) noted that a pure hexagonal street network would only contain three-legged intersections, whereas the elaborate triangular network in other hexagonal plans such as those of Lamb, Müller and Comey contained many intersections which were even more complex than the rectangular grid.

Cauchon unveiled his basic hexagonal plan (Figure 11) at the 1925 International Town, City and Regional Planning Conference in New York. He added a grade-separated 'interceptor' roadway for fast through traffic, and a detailed comparison of similarly sized rectangular and hexagonal blocks. The lot and building layout appear to be influenced by diagrams from Raymond Unwin's Town Planning in Practice: An Introduction to the Art of Designing Cities and Suburbs (1909). The hexagon required 10\% less length of roads and utilities and allowed a substantial central green space in each block (Figure 12).

Cauchon's proposal was well received and reprinted in numerous technical journals (Cauchon, 1925, 1926a,b). He elaborated upon the design with each publication, adding diagrams and detailed calculations which demonstrated the hexagon's superiority over the rectangular grid for residential servicing and traffic flow. By 1927, Cauchon had expanded his theory into a complete plan for Hexagonopolis (Figure 13) on a scale whose boldness rivals that of Le Corbusier's Ville Contemporaine (1922). Cauchon promoted his ideas widely, arranging for Hexagonopolis to be featured in Canada's largest-circulation magazine (Cauchon, 1927), speaking to numerous professional groups and distributing reprints of his articles to hundreds of planning activists in the 1920s.

In addition to engineering and planning benefits, Cauchon also suggested that the hexagonal system had public health benefits. If the hexagonal grid was oriented so that it pointed due north, there would never be buildings with a northern exposure, and all rooms in the block would receive direct sunlight every day. Direct sunlight was identified as a possible cure for tuberculosis in 


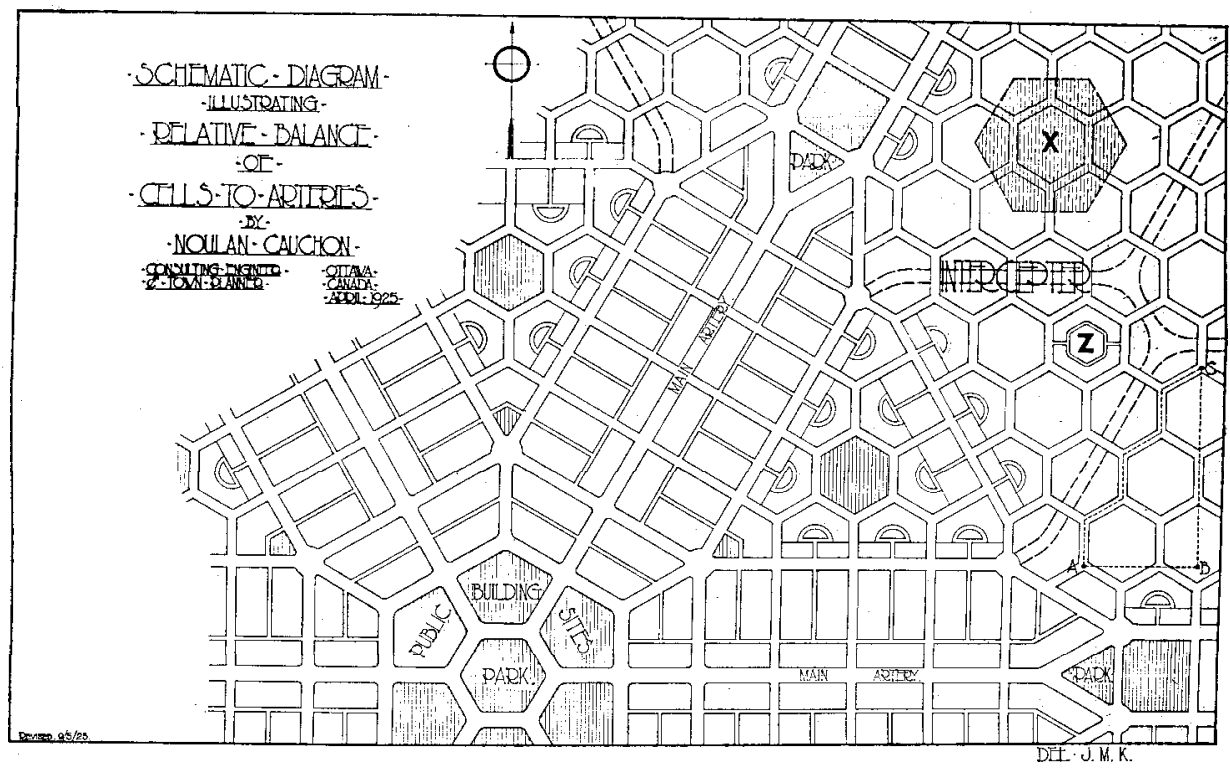

Figure 11. Hexagonal plan, Noulan Cauchon, 1925. Source: Cauchon (1925).

the 1920s and adequate daytime lighting was a strong concern of housing reformers throughout the decade. Lawrence Veiller, the influential secretary of the (US) National Housing Association (NHA) invited Cauchon to the NHA's conference and promoted his work (Cauchon, 1929a; Kitchen, 1929).

Noulan Cauchon's plans were also reprinted in Europe in the 1920s. Georges Benoit-Levy $(1928,1929)$ promoted Hexagonopolis in France, even presenting a hexagonal house to complement it (Figure 14). However, despite Cauchon's scientific analysis and vigorous promotion of his plan, not a single hexagon had been built in North America by 1930. Another powerful alternative to the grid had emerged in New Jersey.

\section{Radburn as a New Suburban Prototype (1928-1934)}

Radburn was designed by Clarence Stein and Henry Wright for a greenfield site in New Jersey, $24 \mathrm{~km}$ from Manhattan. It combined Clarence Perry's neighbourhood unit concept (Perry, 1929) with a radically new street layout.

Stein had recently returned from a trip to England, where he studied the designs of Letchworth and Hampstead Garden Suburb (Parsons, 1992). The Radburn plan adopted Unwin and Parker's cul-de-sac as the exclusive method of residential layout for houses (Figure 15) but combined them in superblocks of 30-50 acres (Stein, 1957). The residential cul-de-sacs were separated by narrow pedestrian paths, which connected to a central park, a playground and a school site. The cul-de-sacs eliminated the grid's problem of through traffic on local streets, and pedestrian underpasses ensured that children did not have to cross a street to reach the parks or school (Stein, 1957). Perry's neighbourhood unit was updated for the motor age.

The Radburn project collapsed in the 1930s depression, but its plan became 


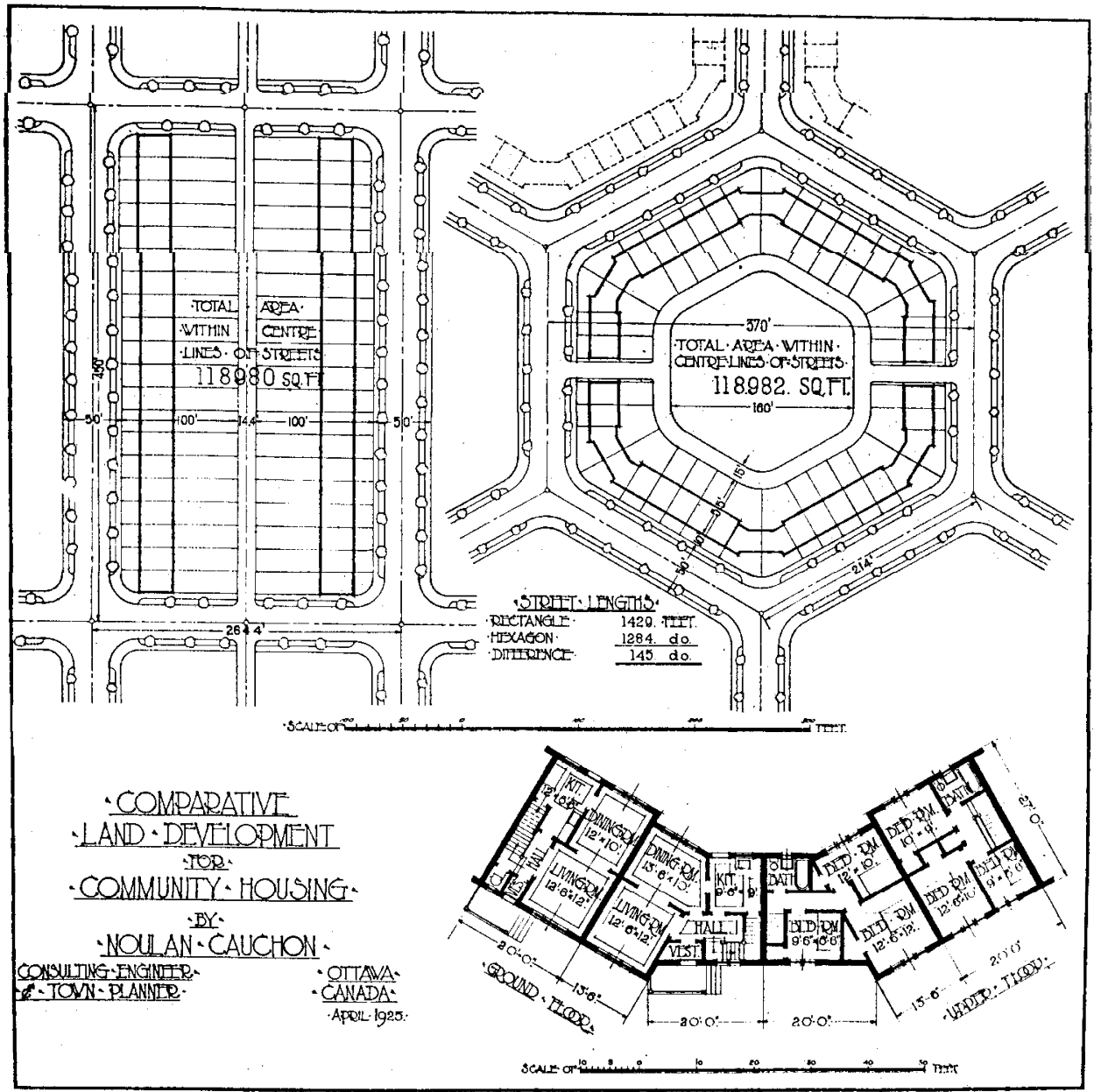

Figure 12. Hexagonal block, Noulan Cauchon, 1925. Source: Cauchon (1925).

widely known due to extensive promotion by various planning groups (Birch, 1980; Silver, 1985). Thomas Adams, now heading the New York Regional Plan, featured it in the background reports of the New York Regional Plan Association, even before its first phase was complete (Adams, 1927). However, this New Jersey fragment was the only built example of the plan in 1928, when Barry Parker built the first hexagonal residential community.

\section{Hexagons in Practice: Barry Parker and Wythenshawe (1928)}

Barry Parker met Noulan Cauchon at the 1925 International Town, City and Regional Planning Conference in New York city. He and Unwin had split by then, with Parker's practice including more site planning and less policy work than Unwin's (Miller, 1992). Cauchon pressed his hexagonal plans upon both UK planners, but only Parker responded. Parker had become immersed in what he often referred to as 'the present motor age' and 'economy of development'. In 1928, he attempted to combine Noulan Cauchon's hexagonal schemes 


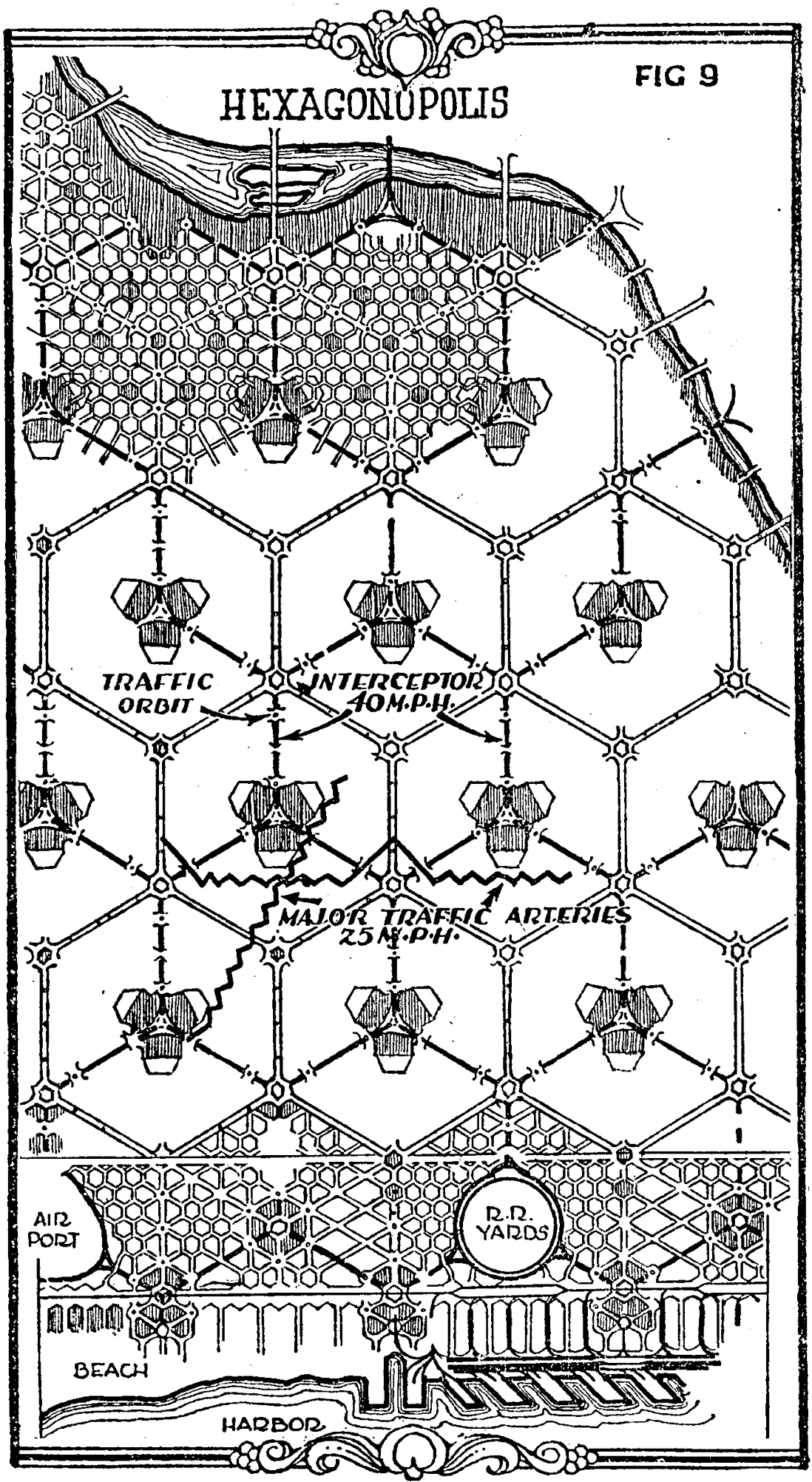

Figure 13. Hexagonopolis, Noulan Cauchon, 1927. Source: Davidson (1927). 


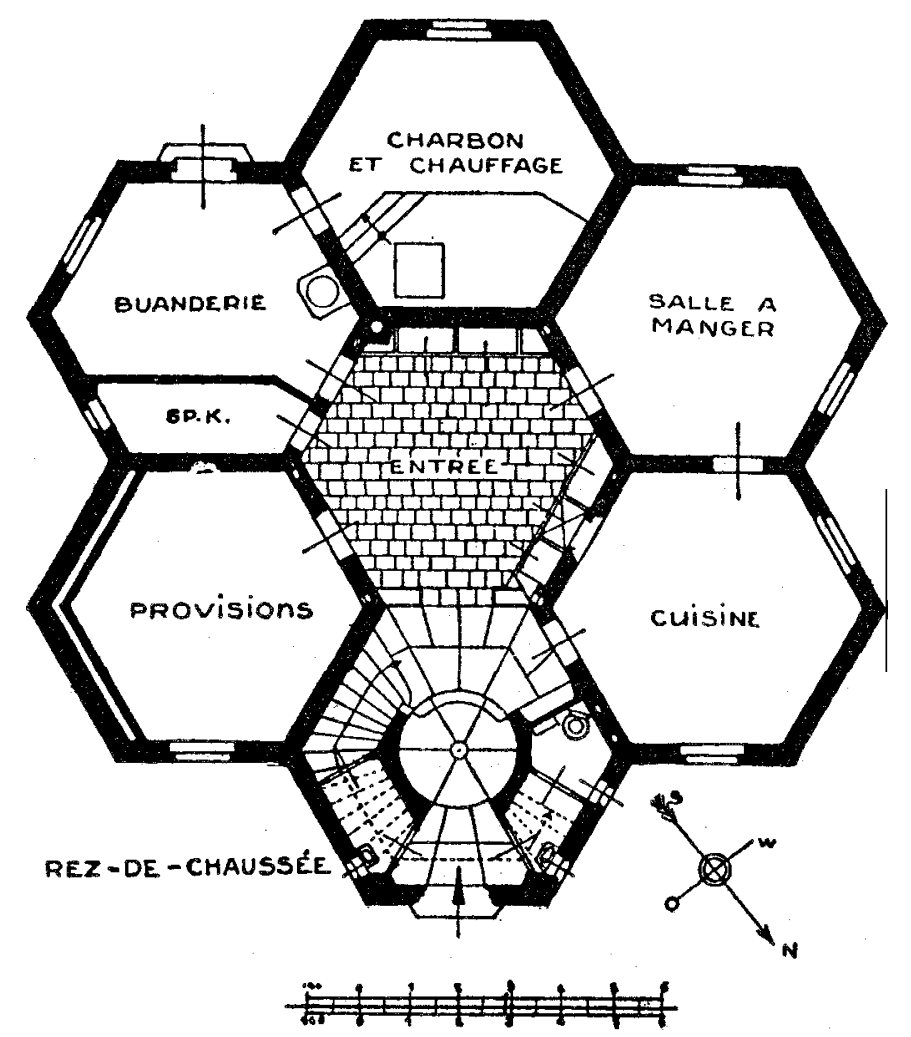

Figure 14. Hexagonal villa, Wilhelm Ulrich, ca. 1927. Source: Benoit-Levy (1929).

with the Radburn plan, first in a theoretical paper and then on the ground at Wythenshawe (Parker, 1928a).

Both Parker and Unwin were advocates of the cul-de-sac. Yet Parker was eager to combine this approach with the US neighbourhood unit principle demonstrated in Radburn. In 'Economy in estate development' (Parker, 1928b) he took his own cul-de-sac design, framed it with a Cauchon hexagon and then put it in the Radburn version of the superblock. The hexagon was particularly attractive for local streets because of its $10 \%$ reduction in the length of road per house. Parker reiterated Cauchon's arguments of economic savings and safety of travel. Parker added a series of diagrams adjusting Cauchon's original hexagonal plan to the superblock concept and argued for further savings (Figure 16):

If we increase the number of houses for which given lengths of roads and services suffice, the costs of maintaining, lighting, supervising, scavenging and draining, our roads will be less and we shorten the rounds of the rent collector, the policeman, the dustman, the postman, the milkman, the banker, the water cart, the doctor and the road surveyor, and the distances we have to go to centres of amusement and recreation, to shop, to the station and to visit our friends. (Parker, 1928 b, p. 185)

The implementation of Parker's theoretical diagrams proved to be difficult. The Wythenshawe satellite town near Manchester was designed by Parker in 1927- 
1928. In his mind it was the perfect example of a garden city as envisioned by Ebenezer Howard (Creese, 1966). Parker designed the 5500 acre site-plan around three US planning principles: the neighbourhood unit, or the superblock; the Radburn cul-de-sac, with separation of pedestrians and cars; and the parkway. He designated a centralized town square, minor shopping centres and primary schools as the cores of his neighbourhoods. He also allocated more than 1000 acres of open space in an agricultural belt which separated the town from the city and provided a pedestrian network. Following the neighbourhood planning principle, Parker divided the site into large sectors for housing purposes, each sector being bounded by traffic routes and having a school near the centre. As in Radburn, children going to and from school have no major traffic roads to cross and the travel distances are reduced to a minimum.

Even though the Wythenshawe plan was considered revolutionary at the time, Parker was unable to fit his hexagon design into most of the plan. The political and economic structure of the development, the fact that the city of Manchester did not obtain full control of the land until 1930, the onset of World War II and an economic depression interfered with its systematic realization (Derick, 1989). While Parker's three concepts are evident in the Wythenshawe master plan, only one hexagonal block in modified form was included in the final site plan (Figure 17).

Although only one hexagonal block was built at Wythenshawe, Parker ensured that the concept would receive world-wide publicity by publishing his plans and analysis in the Journal of the Town Planning Institute and The American City (Parker, 1928b,c; Dougill, 1935) and presenting them at conferences. Cauchon continued to promote hexagonal planning on both sides of the Atlantic (Cauchon, 1929a,b; Kitchen, 1929) so that, by the end of the decade, Radburn and the hexagon were two rival alternatives to the rectangular grid for residential areas. Cauchon's colleague from Ottawa, Thomas Adams, was instrumental in the choice of one design as the standard for US practice.

\section{Subdivision Planning and Regulation: Thomas Adams and President Hoover's Conference on Home Building and Home Ownership, 1932}

After the release of the New York Regional Plan in 1929, Thomas Adams moved to Harvard University to undertake research and write planning textbooks (Simpson, 1985). Like Parker and Cauchon, Adams was concerned with the prevailing methods of city planning and design. He was particularly concerned with inefficient and wasteful practices of subdivision design. In his book, Neighborhoods of Small Homes: Economic Density of Low-cost Housing in America and England (Whitten \& Adams, 1931, p. 87), Adams wrote:

In connection with both the problem of building new houses and improving old houses there is a need of more knowledge of underlying economic conditions. This is particularly so in regard to the cost of land development and the necessity or otherwise of the unhealthful densities of buildings that are allowed to prevail in large cities.

Adams, together with Robert Whitten, the president of the American City Planning Institute, conducted an economic study which compared and analysed different residential designs. Their analysis concentrated on ratios and costs associated with different physical factors such as densities, lot layouts, utilities, street widths and landscaping. 


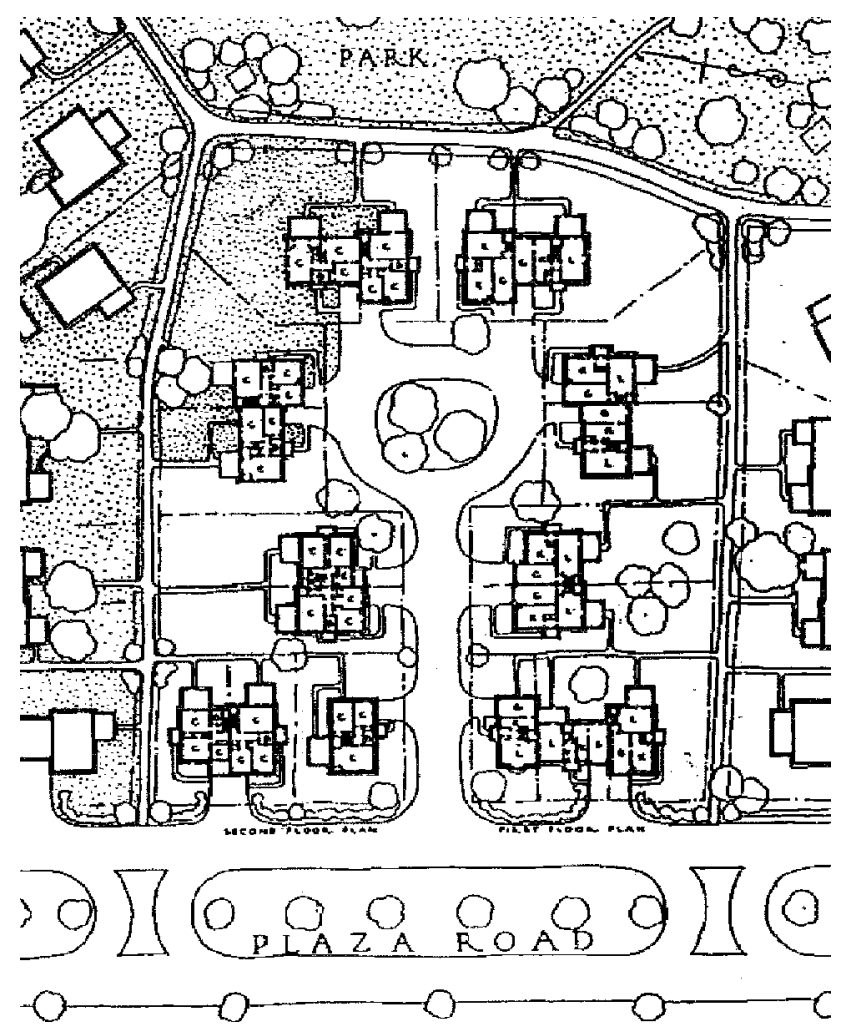

Figure 15. Cul-de-sacs at Radburn, New Jersey, Stein and Wright, 1929. Source: Courtesy Kroch Library, Cornell University.

Adams clearly favoured the Radburn plan, placing a photograph of one of its cul-de-sacs in the frontispiece of the text. However, the hexagonal plan could not be rejected on economic or efficiency grounds since Barry Parker's hexagonal layout actually proved to be the most efficient on these criteria (Figure 18). Adams and Whitten dealt with this difficulty by changing Cauchon's and Parker's designs into the modified hexagon scheme (Figure 19) which afforded "larger vistas and a more restful pattern; it relieves the rigidity and unpleasantness of the street" (Adams, 1934, p. 214). The modified design also had more open space, and development costs which were $4 \%$ higher than those of the favoured cul-de-sac and loops scheme (Figure 20).

To make absolutely certain that the cul-de-sac and loops scheme was regarded as the most economically efficient, higher-density building types, including townhouses and apartments, were added to make the model neighbourhood unit (Figure 21). This denser design was dramatically more cost-efficient, almost $38 \%$ cheaper than Parker's hexagonal layout. Faced with a graph like Figure 18, no builder would hesitate in selecting the model neighbourhood unit.

By the early 1930s, Adams had attained such a prominent standing as an expert in town planning and subdivision development that many of his writings were adopted as recommended practices by government and professional institutions. In 1932, President Hoover's Conference on Home Building and Home 


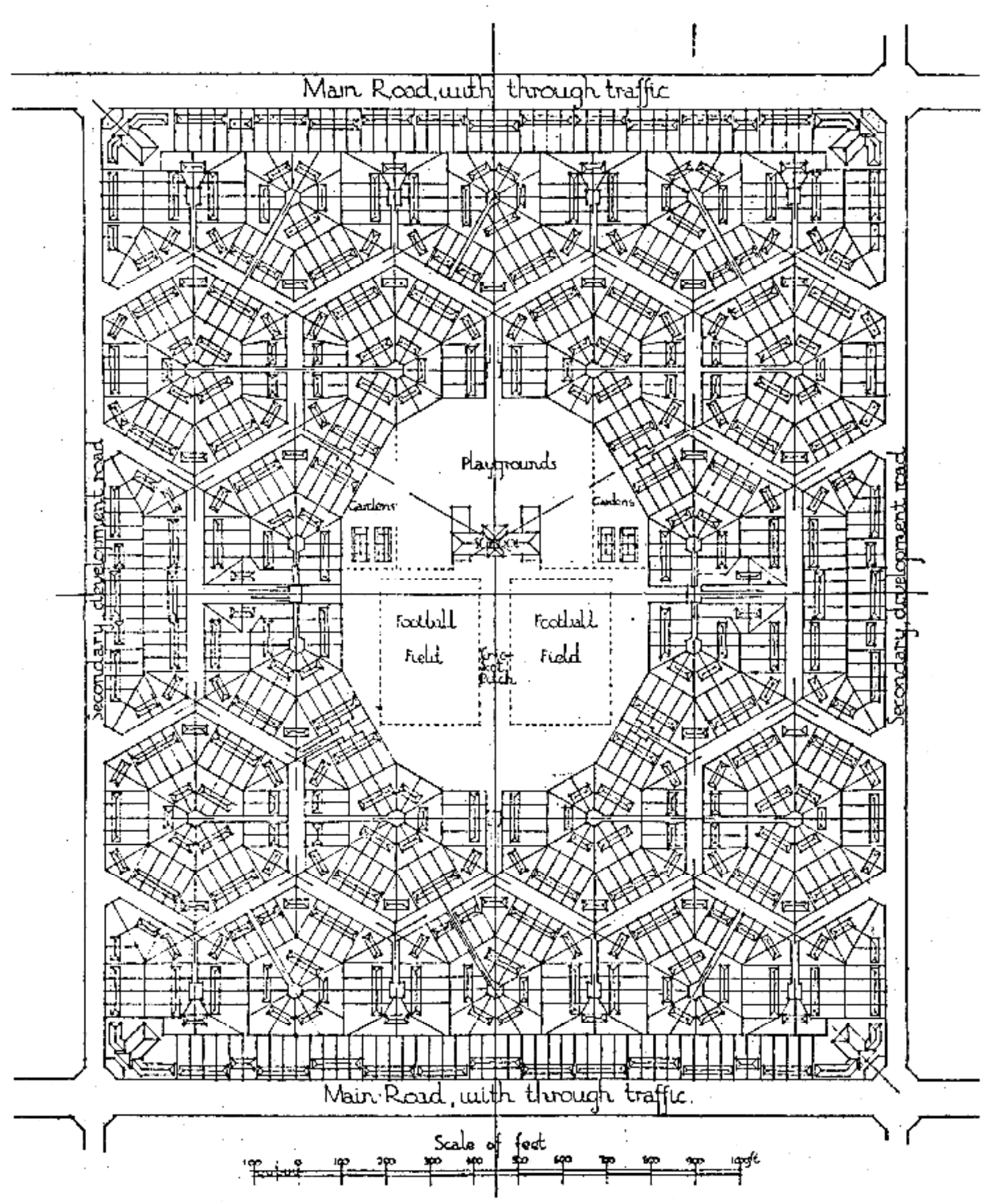

DIAGRam 17

Figure 16. Hexagonal neighbourhood unit, Barry Parker, 1928. Source: Parker (1928b).

Ownership used Adams's suggestions from the draft of his forthcoming book, The Design of Residential Areas (Adams, 1934), as part of its recommended practices. President Hoover's conference was the largest ever held by the federal government up to that time. More than 3700 experts on various aspects of home finance, taxation and the planning of residential districts formed committees and put forward a multitude of recommendations that shaped the built landscape for generations to come. 

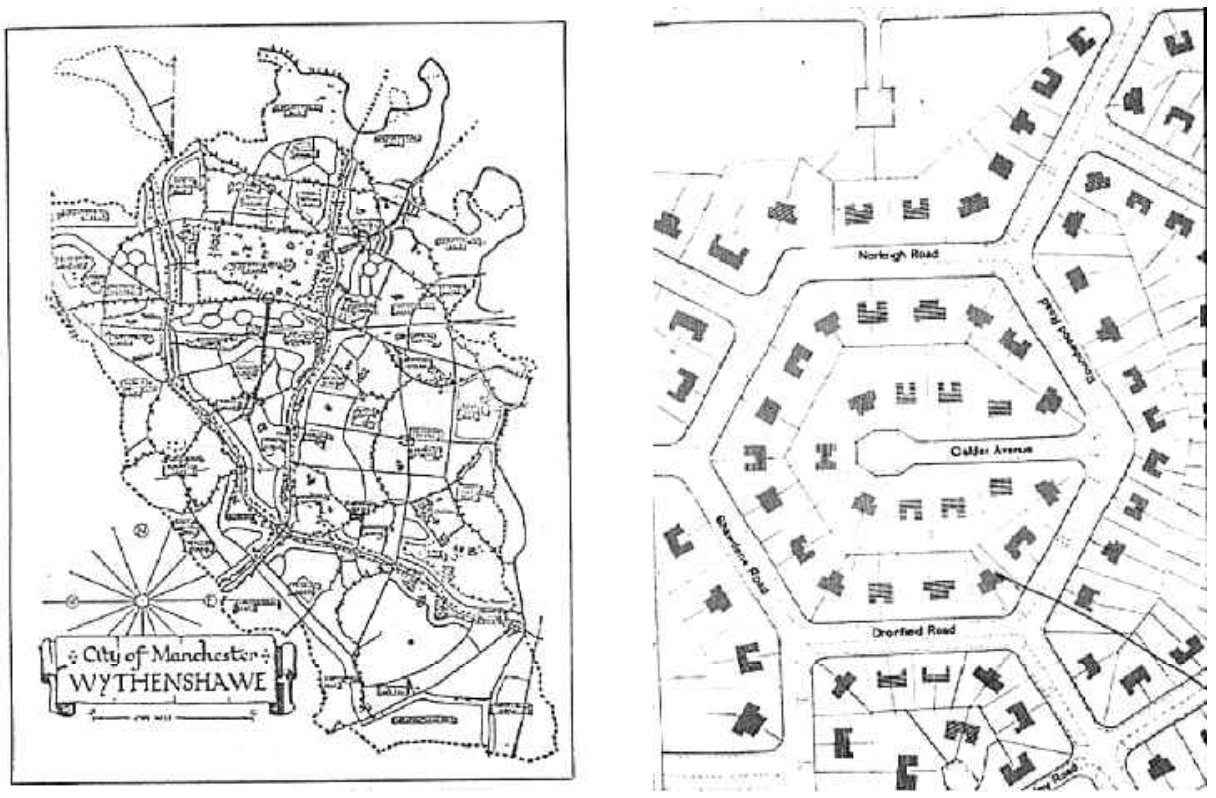

Figure 17. Hexagonal block, Wythenshawe, Barry Parker, 1929. Source: Courtesy of the City of Manchester.

The call for such an extensive conference was rooted in the harsh realities of the economic depression, which crippled US municipal authorities. Limited by depleted local revenues and soaring unemployment rates, many municipalities reached fiscal crisis and approached bankruptcy (Boyer, 1983). Uncontrolled subdivision planning resulted in both unruly layouts and chaotic marketing. As the Committee on Planning for Residential Districts describes:

Too much current practice in municipal development is based upon habit, insufficient vision, excessive speculation in land, and overemphasis of new growth upon the outskirts to the detriment of older sections, which too often become blighted ... Individual action and individual decisions on matters of concern to the whole community have been the rule of community development. Shanty-towns, houses off grade and askew with the street, unsanitary conditions, and unsightly developments have resulted. Suburban slum areas have been created. Subdivision practices and the contribution of municipalities to subdivision development are in need of review and of regulation. (Gries \& Ford, 1932, pp. 1-2)

The conference's subdivision layout subcommittee was established to set new standards and regulations. In its adaptation of Adams's treatise, the committee called for the reduction of subdivision costs through "thoughtful planning and functional layout" (Gries \& Ford, 1932, p. 124). Using Adams's comparative diagrams and charts, it endorsed the neighbourhood unit principle and the interior cul-de-sac as the most economical configuration for residential design. Although the committee put forward the modified hexagonal pattern as one of 


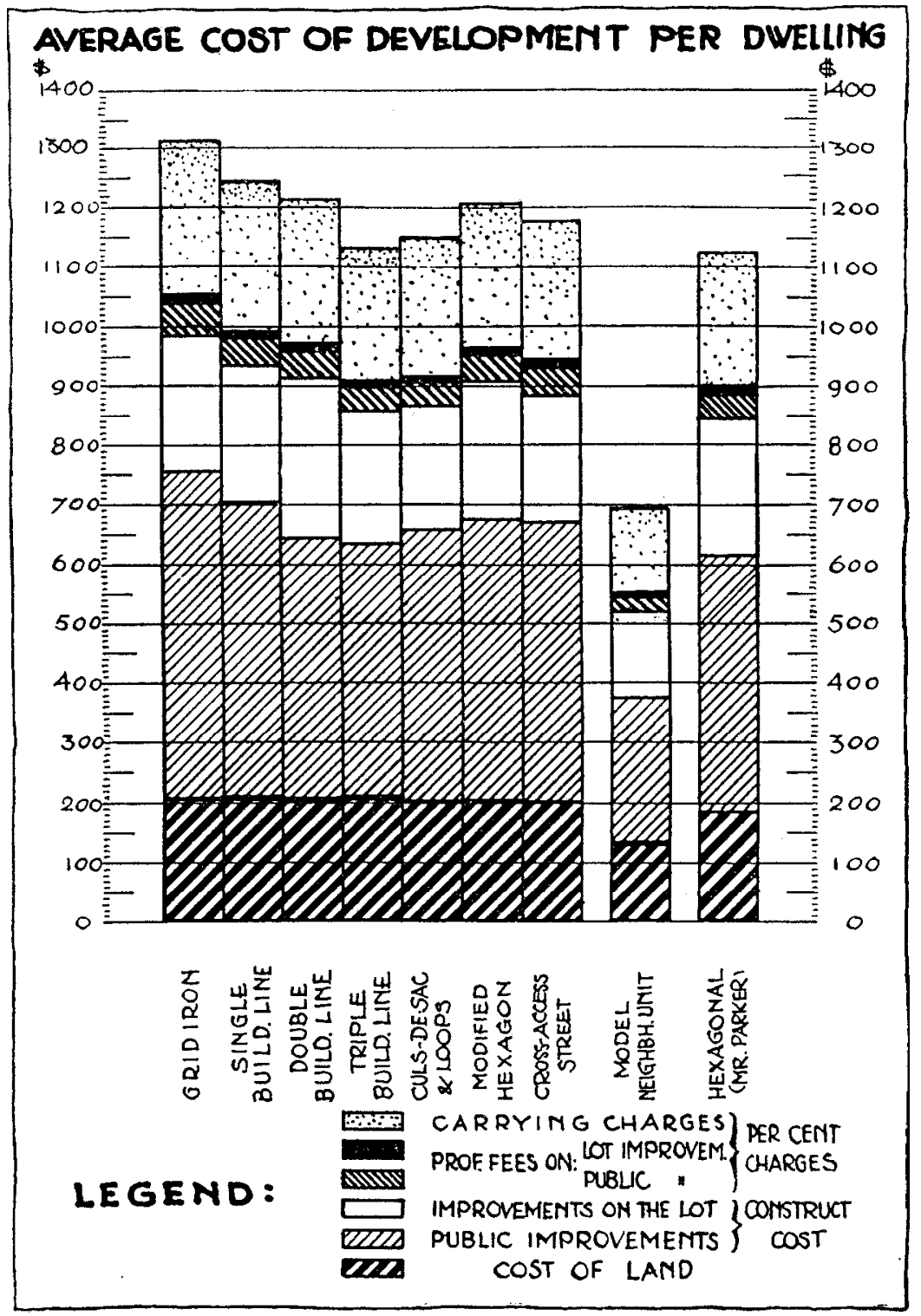

Figure 18. Costs of neighbourhood design types, 1931-1934. Note that Parker's hexagonal plan (extreme right) has the lowest per unit cost. Source: Adams (1934, figure 46).

the most attractive schemes, it also criticized the regular hexagon block as an unfavourable pattern (Figure 19). The committee wrote:

Although there is no doubt that the hexagon may be used in certain cases with advantage, the practical difficulty of its application for low-cost developments is that it produces a large number of oddshaped lots ... A comparison of a square and hexagonal block which 
MODIFIED HEXAGONAL PATTERN

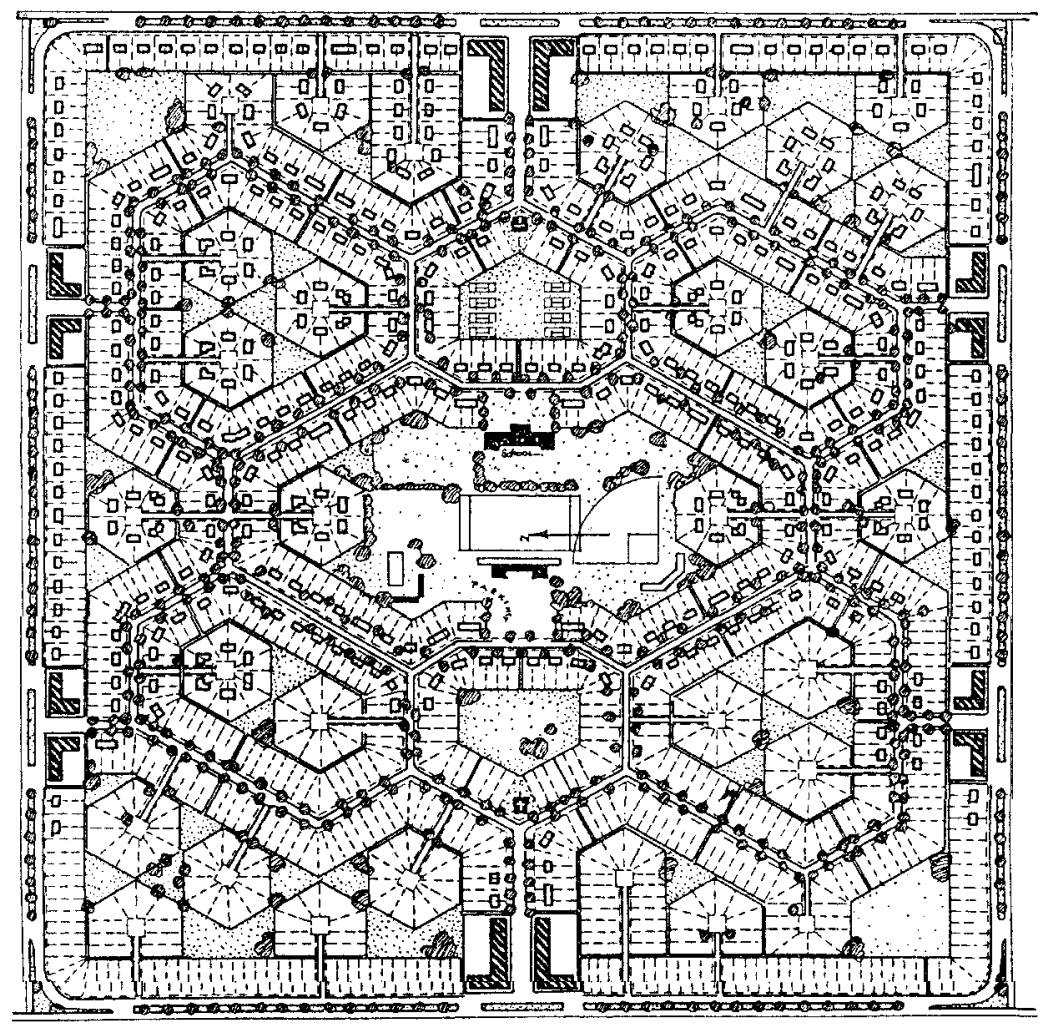

$+\ldots$

Figure 19. Modified hexagonal plan used by Adams and Whitten for analysis. Source: Adams (1934, figure 41).

provides comparable amenities for the same number of lots, shows that the gain in hexagonal block is by far too little to outweigh the obvious disadvantages in regard to streets and lot shapes. The fact that the hexagonal block has always been compared only with the gridiron block has created the impression that it is economically superior to any other layout. The hexagon and the orbit as a basis for the general pattern of the city still has its merits, but its usefulness in applications to smaller units does not compare favorably with other schemes. (Gries \& Ford, 1932, p. 115)

\section{The Demise of Hexagonal Planning}

President Hoover's conference discredited hexagonal layouts, and the model neighbourhood unit of cul-de-sacs and loops was subsequently adapted in government site planning manuals in North America. Stein and Adams's triumph was complete. The depression-era greenbelt plans and the wartime 


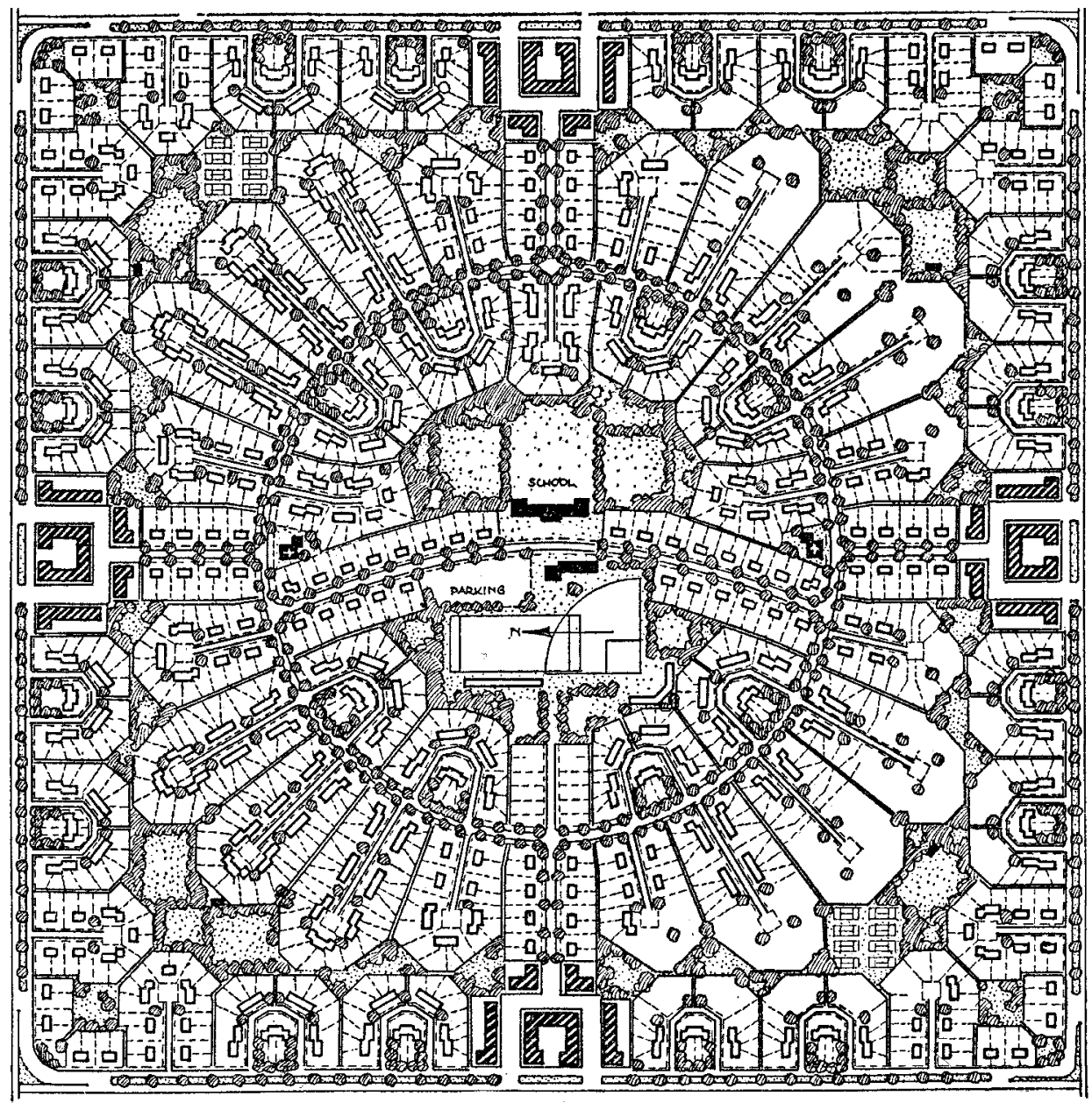

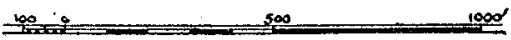

Lratuen C. K. Promenongram

Figure 20. Cul-de-sac and loops scheme preferred by Adams and Whitten. Source: Adams (1934, figure 42).

housing projects were almost all built using the new neighbourhood unit principles (Stein, 1957). Cauchon's death in 1935 and the turmoil of World War II practically put an end to the esoteric pursuit of hexagonal planning.

Radburn was influential, but Adams's regulatory efforts proved to have the greatest effect. The incorporation of the cul-de-sacs and loops design as the alternative to gridirons in federal regulatory documents in the 1930s eventually ensured that the US private building industry adopted this design concept.

In 1935, for example, the Federal Housing Authority (FHA) initiated a series of technical publications which included 'Minimum requirements and desirable standards' (FHA, 1935). These standards required not only adherence to set dimensions and configurations, but also recommendations for development layout which rejected the grid pattern for residential neighbourhoods. The 1936 


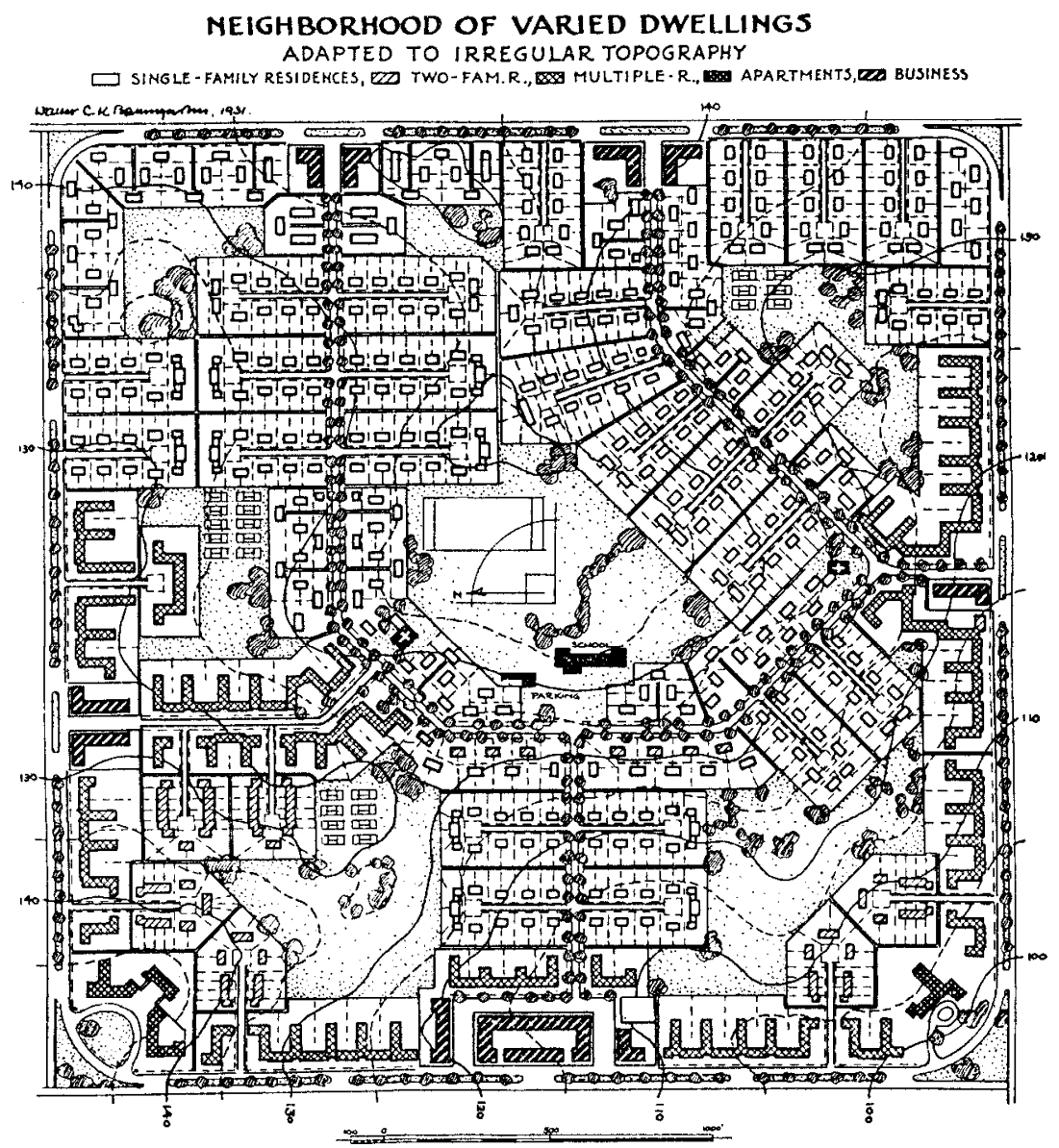

Figure 21. Model neighbourhood unit with increased density added to achieve the per unit savings shown in Figure 18. Source: Adams (1934, figure 47).

bulletin, Planning Neighborhoods for Small Houses (FHA, 1936), demonstrated the FHA preference for the town and neighbourhood planning concepts of Perry, Stein and Adams. Using plans and diagrams borrowed directly from previous publications by these authors, the bulletin illustrated how to build an ideal "well-balanced, carefully planned subdivision", declaring:

The gridiron plan which has been so universally adopted in most of our cities has several very decided disadvantages when applied to residential areas. In the first place, it creates waste by providing a greater paved area than necessarily adequate to serve a residential community. Secondly, it causes the installation of a more expensive type of paving by dispersing the traffic equally through the area, which in turn creates an increased traffic hazard. In addition to these disadvantages, it creates a monotonous uninteresting architectural effect and fails to create a community aspect. (FHA, 1936, p. 12) 
The FHA advocated three basic forms of residential street layouts: curvilinear, cul-de-sacs and courts. Their design was guided by descriptive and prescriptive standards.

The post-war building boom was partially fuelled by new long-term, lowinterest mortgages granted first to veterans and then to the general public (Fishman, 1987). Access to federal mortgages or mortgage insurance was conditional upon adopting the new federal standards in the USA and Canada. Millions of homes were built on loops and cul-de-sacs in the four decades after the war. This residential design model became conventional practice, with little understanding today of the alternatives that were considered at the time it was adopted.

In reality, as well as on paper, hexagonal blocks may have looked too unusual to be a workable solution. How would streets be named or dwellings numbered in a hexagon plan like that in Figure 13? How would strangers navigate the streets of Hexagonopolis? Perhaps more seriously, residential developers and home buyers did not like the triangular lots caused by the inside corners of hexagonal blocks. One-quarter of the lots in Parker's design (Figure 16) had triangular back yards, which are the principal private open spaces in North American suburbs. By contrast, the corner lots in a cul-de-sac (Figure 15) were all the wedge-shaped 'pie-lots' valued by homeowners, because they had a small (public) front yard and a large (private) back yard.

The advantages of hexagonal planning could also be obtained in the cul-desacs and loops scheme, through careful design. Three-way intersections were possible between a cul-de-sac and a collector road, while four-way connections between collector and arterial roads could be controlled by traffic signals. The model Toronto community of Don Mills made this approach standard practice in Canada for many years (Sewell, 1993). A wide angle of view at intersections could be provided by zoning regulations which required larger corner lots with sight triangles. Sunlight access in low-density developments could be protected with side yard regulations in zoning bylaws. Interior parks accessible to pedestrians were provided in the Radburn layout. On the cost of infrastructure, the analysts showed that the two options were close, fudged the numbers a bit and stated that the urban design disadvantages were not worth the marginal improvements in economic efficiency. Perhaps they were right, but we cannot be sure, since there is no hexagonal subdivision to study. The regulators' triumph was too complete.

What happened to hexagonal planning illustrates the futility of street and block planning as the sole concept behind city planning. While it might be commendable for its symmetry on paper, that same virtue might be a fault in practical application. Adams, in Recent Advances in Town Planning (Adams, 1932, p. 158), warned that:

An architectural conception which embraces a combined street lay-out and grouping of proposed buildings for part of a town may not be a complete or satisfactory town plan and may be ineffective in securing even the orderly aesthetic result that is the chief aim of limited design.

Adams's warning is particularly significant today, as urban designers explore alternatives to the residential cul-de-sac and loop plans that he made into conventional suburban practice. 


\section{Acknowledgements}

The author wishes to thank Dr Mervyn Miller for timely advice and drawings for Barry Parker's and Raymond Unwin's hexagonal plans; Dr Robert Hodder for his comments on an early draft; and two anonymous reviewers. The Noulan Cauchon research was assisted by Daniel Tovey and Miguel Tremblay, with guidance from John Taylor and Sally Coutts. Financial support was provided by the Social Sciences and Humanities Research Council of Canada, Queen's University's Advisory Research Council and the Richardson Fund. The paper was originally presented by Eran Ben-Joseph at the 1997 Association of Collegiate Schools of Planning (ACSP) Conference.

\section{References}

Adams, T. (Ed.) (1906) Guide to the Garden City (London, First Garden City Ltd), reprinted by the Letchworth Public Library, 1986.

Adams, T. (1921) Editorial: town planning is a science, Journal of the Town Planning Institute of Canada, 1 (3), pp. 1-3.

Adams, T. (1927) Planning the New York Region: An Outline of the Organization, Scope and Progress of the Regional Plan (New York, NY, New York Regional Plan Association).

Adams, T. (1932) Recent Advances in Town Planning (New York, Macmillan).

Adams, T. (1934) The Design of Residential Areas (Cambridge, MA, Harvard University Press).

Benoit-Levy, G. (1928) Hexagonopolis, La Technique du Traveaux, May, pp. 316-318.

Benoit-Levy, G. (1929) L'habitation hexagonal, La Technique du Traveaux, August, pp. 417-421.

Birch, E.L.L. (1980) Radburn and the American planning movement: the persistence of an idea, Journal of the American Planning Association, 47(4), pp. 424-439.

Boyer, C. (1983) Dreaming the Rational City: The Myth of American City Planning (Cambridge, MA, MIT Press).

Buchanan, C. (1963) Traffic in Towns (London, Penguin).

Castagnoli, F. (1971) Orthogonal Town Planning in Antiquity (Cambridge, MA, MIT Press).

Cauchon, N. (1925) Hexagonal blocks for residential districts, The American City, 17, pp. 145-146.

Cauchon, N. (1926a) Hexagonal planning, traffic intercepter, and orbit, paper presented at the meeting of the City Planning Division, American Society of Civil Engineers, New York City, 21 January.

Cauchon, N. (1926b) Hexagonal planning: health properties, The Nation's Health, January, p. 40. Copy annotated by N. Cauchon in Cauchon papers, National Archives of Canada, Ottawa, MG 30 C105.

Cauchon, N. (1927) Planning organic cities to obviate congestion: orbiting traffic by hexagonal planning and intercepters, Planning for City Traffic-The Annals of the American Academy of Political and Social Sciences, 133, pp. 241-246.

Cauchon, N. (1929a) Hexagonal planning and housing, Proceedings of the Tenth National Conference on Housing, Philadelphia, January 1929 (New York, NHA).

Cauchon, N. (1929b) The six-sided block, National Real Estate Journal, 18 March, pp. 42-46.

Christaller, W. (1966) Central Places in Southern Germany, translated from Die zentralen Orte in Süddeutschland (1933) by Carlisle W. Baskin (Englewood Cliffs, NJ, Prentice-Hall).

Comey, A. (1923) Regional Planning Theory: A Reply to the British Challenge (Augusta, ME, C.E. Nash).

Coutts, S. (1982) Science and sentiment: the planning career of Noulon Cauchon, unpublished MA thesis, Department of History, Carleton University.

Creese, W. (1966) The Search for New Environment: The Garden City Before and After (New Haven, CT, Yale University Press).

Davidson, M. (1927) Six cylinder cities, The Toronto Star Weekly, 18 June, p. 21.

Derick, D. (Ed.) (1989) Wythenshawe: The Story of a Garden City (Chichester, Phillimore).

Dougill, W. (1935) Wythenshawe: a modern satellite town, The Town Planning Review, 16(3), pp. 209-215.

Federal Housing Administration (FHA) (1935) Subdivision Development, Circular No. 5, January 10 (Washington, DC, FHA).

Federal Housing Administration (FHA) (1936) Planning Neighbourhoods for Small Houses, Technical Bulletin No. 5, July 1 (Washington, DC, FHA). 
Fishman, R. (1987) Bourgeois Utopias: The Rise and Fall of Suburbia (New York, Basic Books).

Gilmartin, G. (1995) Shaping the City (New York, Clarkson Potter).

Gordon, D.L.A. (1998) A City Beautiful plan for Canada's capital: Edward Bennett and the 1915 plan for Ottawa and Hull, Planning Perspectives, 13, pp. 275-300.

Gries, J. \& Ford, J. (Eds) (1932) Planning Residential Districts: City Planning Subdivisions, Utilities, Landscape Planning (Washington, DC, National Capitol Press).

Howard, E. (1898) Tomorrow: A Peaceful Path to Real Reform (London, Swan Sonnenschein).

Johnston, N.J. (1983) Cities in the Round (Seattle, WA, University of Washington Press).

Kitchen, J. (1929) Hexagonal planning, Proceedings of the Tenth National Conference on Housing, Philadelphia, January (New York, NHA).

Kostof, S. (1991) The City Shaped: Urban Patterns and Meanings through History (London, Bulfinch Press).

Lamb, C. (1904) City plan, The Craftsman, 6, pp. 3-13.

Miller, M. (1989) Letchworth: The First Garden City (Chichester, Phillimore).

Miller, M. (1992) Raymond Unwin: Garden Cities and Town Planning (Leicester, Leicester University Press).

Müller, R. (1908) The city of the future: hexagonal building concept for a new division, Österreichische Wochenschrift für den öffentlich Baudienst, 14. Available online (30 June 1999) at http:// www.library.cornell.edu/Reps/DOCS/muller.htm.

Olmsted, F.L., Jr (1910) Street-traffic studies, Landscape Architecture, 1 (1), pp. 1-8. Copy annotated by N. Cauchon in Noulan Cauchon papers, National Archives of Canada, Ottawa, MG 30 C105.

Olmsted, F.L., Jr (1911) The City Beautiful, The Builder, 101, 7 July, pp. 15-17.

Parker, B. (1928a) Report to the Wythenshawe Committee of the Corporation of Manchester, May. Copy annotated by N. Cauchon in Noulan Cauchon papers, National Archives of Canada, Ottawa, MG 30 C105.

Parker, B. (1928b) Economy in estate development, Journal of the Town Planning Institute, 14 (8), pp. 177-186.

Parker, B. (1928c) Economy, charm and safety of the cul-de-sac street, The American City, 20, pp. 104-106.

Parsons, K.C. (1992) British and American community design: Clarence Stein's Manhattan transfer, 1924-74, Planning Perspectives, 7, pp. 191-210.

Parsons, K.C. (Ed.) (1998) The Writings of Clarence S. Stein: Architect of the Planned Community (Baltimore, MD, Johns Hopkins University Press).

Perry, C.A. (1929) The neighborhood unit, in: T. Adams (Ed.) Neighborhood and Community Planning, Regional Plan of New York and the Environs, Vol. VII (New York, New York Regional Plan Association).

Reps, J.W. (1969) Town Planning in Frontier America (Princeton, NJ, Princeton University Press).

Robinson, C.M. (1904) Modern Civic Art; Or The City Made Beautiful (New York, Putman). Copy annotated by Noulan Cauchon in Library of the National Capital Commission, Ottawa.

Sewell, J. (1993) The Shape of the City: Toronto Struggles with Modern Planning (Toronto, University of Toronto Press).

Silver, C. (1985), Neighborhood planning in historical perspective, Journal of the American Planning Association, 52(2), pp. 161-174.

Simpson, M. (1985) Thomas Adams and the Modern Planning Movement: Britain, Canada and the United States, 1900-1940 (London, Alexandrine Press).

Stein, C.S. (1957) Toward New Towns for America (New York, Reinhold Pub. Corp.).

Triggs, I. (1909) Town Planning Past Present and Possible (London, Methuen). Copy annotated by Noulan Cauchon in Library of the National Capital Commission, Ottawa.

Unwin, R. (1909) Town Planning in Practice; An Introduction to the Art of Designing Cities and Suburbs (London, T. Fisher Unwin). Copy annotated by Noulan Cauchon in Library of the National Capital Commission, Ottawa.

Whitten, R. \& Adams, T. (1931) Neighbourhoods of Small Homes: Economic Density of Low-cost Housing in America and England (Cambridge, MA, Harvard University Press).

Wilson, W.H. (1989) The City Beautiful Movement (Baltimore, MD, Johns Hopkins University Press). Yeates, M.A. (1998) The North American City (New York, Longman). 